\title{
30. ORGANIC GEOCHEMISTRY OF CRETACEOUS BLACK SHALES FROM DEEP SEA DRILLING PROJECT SITE 530, LEG 75, EASTERN SOUTH ATLANTIC ${ }^{1}$
}

\author{
G. Deroo ${ }^{2}$ and J. P. Herbin, Institut Français du Pétrole, Direction de Recherche Geologie et Géochimie, B.P. 311, \\ 92506 Rueil-Malmaison Cedex, France \\ and \\ A. Y. Huc, Institut de Recherche, Ressources et Materiaux Mineraux, Université d'Orléans, Orléans Cedex, France
}

\begin{abstract}
Five-hundred ten meters of Cretaceous sediments were drilled north of the Walvis escarpment in Hole 530A during Leg 75. An immature stage of evolution for organic matter can be assigned to all the samples studied.

Black shales are interbedded with red and green claystone in the bottom sedimentary unit, Unit 8, which is of Coniacian to late Albian age. The richest organic carbon contents and petroleum potentials occur in the black shales. Detrital organic matter is present throughout the various members of a sequence, mixed with largely oxidized organic matter in the gray and green claystone or marlstone members on both sides. Detrital organic matter also characterizes the black streaks observed in the claystones. Vertical discontinuities in organic matter distribution are assigned to slumping. Several types of black shales can be identified, according to their content of detrital organic matter, the more detrital black levels corresponding to the Albian-Cenomanian period.

Cyclic variations of organic matter observed for a sequence can occur for a set of sequences and even for some consecutive sets of sequences. Climatic factors are proposed to account for the cyclic sedimentation and distribution of organic matter for every sequence that includes a black bed.
\end{abstract}

\section{INTRODUCTION}

Hole 530A (drilled during Leg 75) is located in the southeastern corner of the Angola Basin about $20 \mathrm{~km}$ north of the Walvis escarpment near the eastern end of the Walvis Ridge (Fig. 1). One hundred sixty-three meters of black shale facies of Cretaceous age were penetrated before basalt was reached. Eight lithological units were described from the recovered section with Units 5 to 8 corresponding to the Cretaceous series (Fig. 2).

Dark green mudstone and marlstone characterize the whole of Unit 5 in the Maestrichtian, and sequences of turbidites are observed. Clastic limestone is found in Subunit 5a, additional siliciclastic sandstone in Subunit $5 \mathrm{~b}$, and calcareous siliciclastic sandstone in Subunit $5 \mathrm{c}$. Volcanogenic sandstone defines Unit 6, which is of Santonian age, and sands occur as thin- to thick-graded turbidites. Variegated red and green claystone, siltstone, and sandstone occur in numerous repeated turbidite sequences in Unit 7, of Santonian to Coniacian age. Black shales interbedded in red and green claystone characterize Unit 8, which is of Coniacian to late Albian age. Horizontal laminations and low-angle ripple cross-laminations suggest that fine-grained turbidites are interbedded with basinal pelagic sediments.

The sediments in Units 8 through 6 make up a classic progradational submarine fan sequence, progressing from basinal (Unit 8) to thick upper-fan channel sandstones (Unit 6). A thinning and fining-upward channel-

\footnotetext{
${ }^{1}$ Hay, W. W., Sibuet, J.-C., et al., Init. Repts. DSDP, 75: Washington (U.S. Govt. Printing Office).

2 Present address: Institut Français du Pétrole, Direction de Geologie et Géochimie, B.P. 311, 92506 Rueil-Malmaison Cedex, France.
}

filled sequence follows in Subunit 5c (Stow, this volume).

Based upon nannoplanktons studied on board, the top of the Coniacian (in Units 7 and 8) was placed in Core 78, and the bottom of the Coniacian was placed in Section 530A-94-1. A hiatus representing the late Turonian is located between $94, C C$ and $95-2$. The lower Turonian was found in the latter section, and the upper $\mathrm{Ce}$ nomanian extends to Sections 96-2 and 97-3. An early Cenomanian to late Albian age was determined for Cores 98 to 105 at the bottom of the sediment. ${ }^{3}$

The present study was performed to characterize geochemically the organic matter (OM) present in the Cretaceous black shales. Specific questions concerning the black-shale facies found along Unit 8 are as follows:

1) Did the organic matter in the black-shale beds originate primarily from material transported by turbidity currents?

2) Are anoxic conditions required for the preservation of the organic matter found in the fine-grained distal turbidites?

3) If so, is a high biological oxygen demand at the water/sediment interface the main control for anoxic conditions?

3) Finally, what mechanism can be proposed to explain the cyclic variations in the amount of organic matter observed throughout the sedimentation of the blackshale unit?

To address these questions, one must consider both the organic matter and the enclosing sediments. For this

\footnotetext{
${ }^{3}$ Revisions of stratigraphic ages are given in Steinmetz et al., this volume.
} 


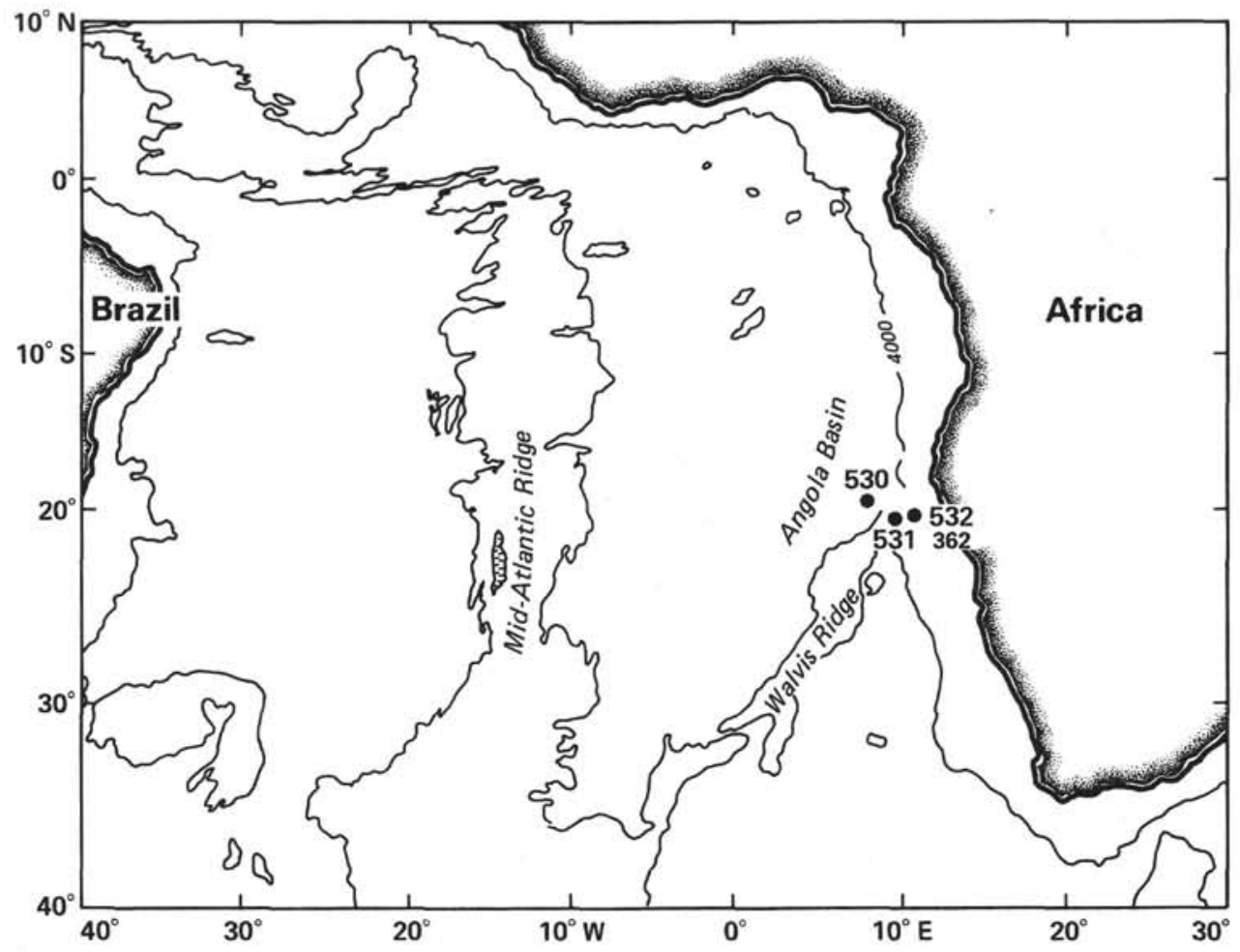

Figure 1. Location map of Leg 75 and Sites 530, 531, and 532.

purpose three steps were followed during the study, according to three different scales. The first scale is a sequence some $40-\mathrm{cm}$ thick, centered on an individual black bed $8-\mathrm{cm}$ thick, with green claystones on both sides. The second corresponds to a bundle of five consecutive black-shale beds with interbedded green claystones beds along an interval $105-\mathrm{cm}$ thick. The third applies to 35 other black beds or sequences selected from among a total of 260 black-shale beds detected within the $163 \mathrm{~m}$ of lithologic Unit 8 (Fig. 3).

\section{METHODS}

Organic carbon was determined in acid-treated samples with a Leco apparatus, except for the closely spaced sampling of Sections 101-1 and 101-2 (Table 1) along which 79 samples were collected over a $40-\mathrm{cm}$ interval. The small size of these samples required a specific analytical procedure to be used. Organic carbon was analyzed in carbonaceous residue issuing from Rock-Eval analysis. The method is based on combustion in a constant oxygen flow at a temperature programmed from 250 to $600^{\circ} \mathrm{C}$ at a linear rate of $25^{\circ} \mathrm{C} / \mathrm{min}$. The $\mathrm{CO}_{2}$ was measured by a nondispersive infrared detector. Because of the small size of the samples (about $30 \mathrm{mg}$ ), significant LECO analyses could not be performed so as to compare the two methods.

Since data of $0.20 \mathrm{wt} . \%$ and less are questionable as a rule, their use and meaning are doubtful.

Pyrolysis assays were performed for all 194 samples with a RockEval (Espitalié et al., 1977). Three intervals were then resampled in the black-shale bed in Core 101 to collect 5 to $6 \mathrm{~g}$ of rock per sample. The three samples obtained were chloroform extracted. Then the extracts were fractionated. A quantitative detection for saturated, aromatic, and heteroatomic NSO fractions was attempted with an Iatroscan analyzer. It consisted, after fractionation had been performed on thin and silicagel-coated rods, in passing them along a flame ionization detector. Every fraction requires $10 \mu \mathrm{g}$ to be analyzed. Hydrocarbon fractions were examined by gas chromatography. Kerogen concentrates (Huc et al., 1978) from three other selected samples were pre- pared. Elemental analysis and optical examination in natural light were performed on these.

\section{RESULTS}

This chapter is divided into six major sections. First, the maturation of organic matter will be examined throughout the Cretaceous series. The second and third sections will be devoted to the characterization of organic matter along a lithological sequence, and the fourth will examine organic matter for the various sequences in Unit 8. The fifth section will examine organic matter in the other Cretaceous units. Finally, we will attempt to explain the sedimentation and distribution of organic matter in the black-shale unit.

\section{Maturation of Organic Matter}

The temperatures reached for maximum hydrocarbon production $\left(T_{\max }\right)$ during Rock-Eval pyrolysis depend both on the stage of maturation and the nature of the organic matter.

A diagram in which $T_{\max }$ is plotted against hydrogen indices (Fig. 4) can be used to estimate the maturation of samples. Evolution paths for the three reference types of organic matter (Types I, II, and III) are outlined in the diagram. When maturation increases, hydrogen indices decrease, whereas the corresponding temperatures of pyrolysis increase. The variation follows the trend of the evolution paths. Some isoreflectance curves superimposed on the diagram can be used to refer to the maturation scale compiled from vitrinite reflectance data. Isoreflectance curve 0.5 defines the boundary between immature and mature organic matter. It roughly corresponds to a $T_{\max }$ in the $430-435^{\circ} \mathrm{C}$ range for mate- 

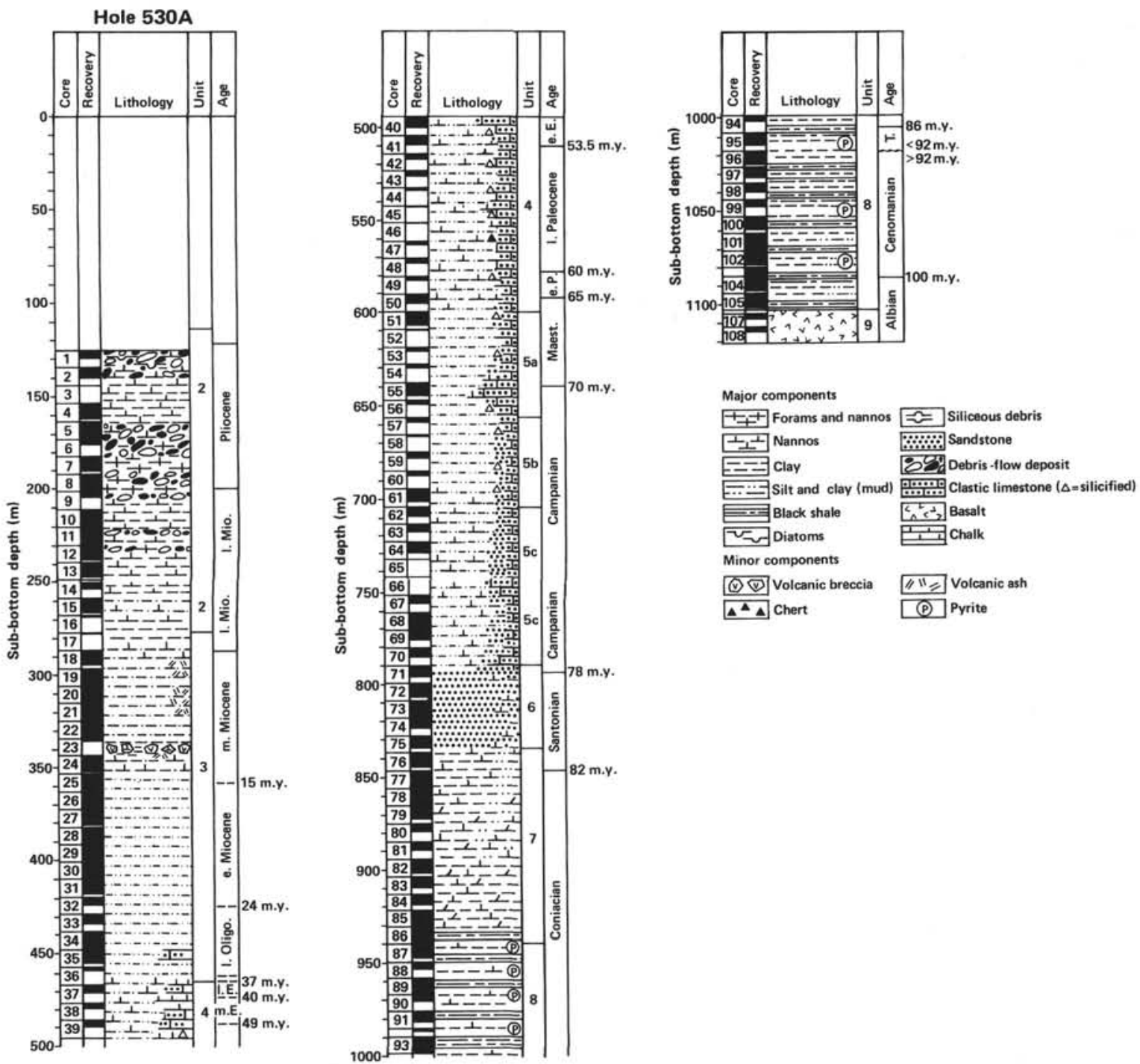

Figure 2. Lithologic and stratigraphic columns for Hole 530A. (Revisions of stratigraphic ages are given in Steinmetz et al., this volume.)
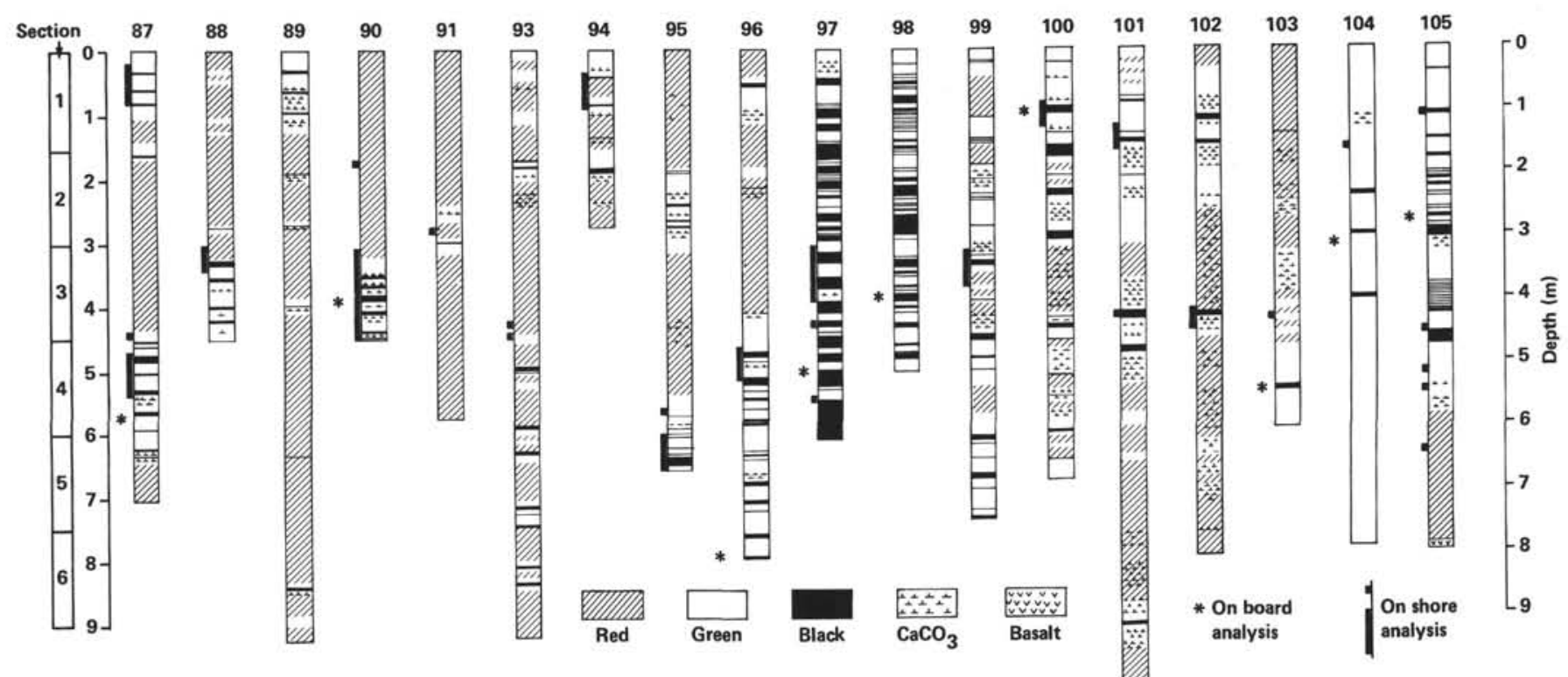

Figure 3. Lithological section of Unit 8 and sampling. 
Table 1. Sample depth, carbon, and pyrolysis assay data, Core 530A-101.

\begin{tabular}{|c|c|c|c|c|c|c|c|c|}
\hline $\begin{array}{c}\text { Section } \\
\text { (Level in } \mathrm{cm} \text { ) }\end{array}$ & $\begin{array}{l}\text { Depth } \\
\text { below } \\
\text { seafloor } \\
\text { (m) }\end{array}$ & $\begin{array}{l}\text { Mineral } \\
\text { carbon } \\
\text { (wt.\%) }\end{array}$ & $\begin{array}{l}\text { Organic } \\
\text { carbon } \\
\text { (wt.\%) }\end{array}$ & $\begin{array}{c}\text { Hydrogen } \\
\text { index } \\
\text { (mg } \mathrm{HC} / \mathrm{g} \mathrm{OC} \text { ) }\end{array}$ & $\begin{array}{c}\text { Oxygen } \\
\text { index } \\
\text { (mg } \mathrm{CO}_{2} / 8 \mathrm{OC} \text { ) }\end{array}$ & $\begin{array}{l}\text { Hydrocarbon } \\
\text { compounds } \\
\text { (mg/g } \\
\text { rock) }\end{array}$ & $\begin{array}{l}\text { Carbon } \\
\text { dioxide } \\
\text { (mg/g } \\
\text { rock) }\end{array}$ & $\begin{array}{c}\text { Pyrolysis } \\
\text { temperature } \\
\left({ }^{\circ} \mathrm{C}\right)\end{array}$ \\
\hline \multicolumn{9}{|l|}{ Section 1} \\
\hline 136.0 & 1063.36 & 1.1 & 1.11 & 89 & 105 & 1.00 & 1.16 & 424 \\
\hline 136.3 & 1063.36 & & 0.97 & 95 & 121 & 0.94 & 1.17 & 425 \\
\hline 136.7 & 1063.36 & & 0.96 & 85 & 136 & 0.81 & 1.31 & 423 \\
\hline 137.0 & 1063.37 & 3.7 & 0.08 & 0 & 1300 & 0.01 & 1.04 & \\
\hline 137.4 & 1063.37 & & 0.08 & 56 & 1275 & 0.04 & 1.02 & 423 \\
\hline 138.1 & 1063.38 & & 0.06 & 0 & 1867 & 0.02 & 1.12 & \\
\hline 138.8 & 1063.38 & 1.9 & 0.05 & 0 & 1360 & 0.03 & 0.68 & \\
\hline 139.2 & 1063.39 & & 0.10 & 0 & 770 & 0.02 & 0.77 & \\
\hline 139.8 & 1063.39 & 2.9 & 0.33 & 68 & 421 & 0.24 & 1.39 & 416 \\
\hline 140.1 & 1063.40 & 2.3 & 0.05 & 0 & 1580 & 0.02 & 0.79 & \\
\hline 140.6 & 1063,40 & & 0.05 & 0 & 2100 & 0.01 & 1.05 & \\
\hline 140.8 & 1063.40 & & 0.03 & 0 & 2667 & 0.01 & 0.80 & \\
\hline 141.1 & 1063.41 & & 0.06 & 0 & 1050 & 0.01 & 0.63 & \\
\hline 141.5 & 1063.41 & & 0.08 & 0 & 550 & 0.01 & 0.44 & \\
\hline 142.2 & 1063.42 & 2.4 & 0.04 & 0 & 950 & 0.01 & 0.38 & \\
\hline 142.8 & 1063.42 & & 0.24 & 38 & 217 & 0.10 & 0.52 & 414 \\
\hline 143.4 & 1063.43 & 2.7 & 0.25 & 68 & 304 & 0.18 & 0.76 & 412 \\
\hline 143.7 & 1063.43 & & 0.23 & 66 & 370 & 0.17 & 0.85 & 418 \\
\hline 143.9 & 1063.43 & 1.3 & 0.16 & 0 & 106 & 0.01 & 0.17 & \\
\hline 144.4 & 1063.44 & 1.9 & 1.34 & 122 & 63 & 1.64 & 0.84 & 427 \\
\hline 144.8 & 1063.44 & & 1.30 & 118 & 55 & 1.54 & 0.71 & 427 \\
\hline 145.4 & 1063.45 & & 1.46 & 154 & 38 & 2.25 & 0.56 & 424 \\
\hline 145.7 & 1063.45 & & 1.67 & 149 & 34 & 2.48 & 0.57 & 427 \\
\hline 145.9 & 1063.45 & 1.3 & 2.13 & 210 & 29 & 4.47 & 0.62 & 425 \\
\hline 146.6 & 1063.46 & 0.0 & 3.00 & 283 & 31 & 8.48 & 0.94 & 427 \\
\hline 147.3 & 1063.47 & 0.9 & 3.33 & 272 & 44 & 9.20 & 1.45 & 421 \\
\hline 147.5 & 1063.47 & 1.0 & 3.08 & 270 & 27 & 8.35 & 0.84 & 425 \\
\hline 148.0 & 1063.48 & & 3.35 & 273 & 30 & 9.15 & 1.00 & 425 \\
\hline 148.8 & 1063.48 & 0.5 & 2.84 & 269 & 38 & 7.67 & 1.09 & 427 \\
\hline 149.4 & 1063.49 & 1.2 & 1.46 & 145 & 43 & 2.12 & 0.63 & 425 \\
\hline 149.5 & 1063.49 & 1.6 & 1.84 & 172 & 39 & 3.18 & 0.71 & 425 \\
\hline \multicolumn{9}{|l|}{ Section 2} \\
\hline 0.1 & 1063,50 & 0.5 & 1.43 & 162 & 53 & 2.32 & 0.76 & 425 \\
\hline 0.9 & 1063.50 & 0.7 & 1.65 & 152 & 48 & 2.55 & 0.79 & 423 \\
\hline 1.1 & 1063.51 & 0.6 & 1.40 & 126 & 47 & 1.77 & 0.66 & 427 \\
\hline 1.7 & 1063.51 & 1.3 & 1.56 & 130 & 26 & 2.04 & 0.40 & 427 \\
\hline 2.2 & 1063.52 & 2.3 & 1.37 & 141 & 47 & 1.93 & 0.65 & 424 \\
\hline 2.8 & 1063.52 & & 0.97 & 123 & 40 & 1.22 & 0.39 & 425 \\
\hline 3.1 & 1063.53 & 2.1 & 0.99 & 120 & 48 & 1.21 & 0.48 & 421 \\
\hline 3.5 & 1063.53 & & 0.50 & 99 & 88 & 0.51 & 0.44 & 416 \\
\hline 4.3 & 1063.54 & & 0.29 & 87 & 52 & 0.25 & 0.15 & 412 \\
\hline 5.0 & 1063.55 & & 0.27 & 87 & 96 & 0.24 & 0.26 & 411 \\
\hline 5.9 & 1063.55 & 2.2 & 0.09 & 117 & 278 & 0.11 & 0.25 & 354 \\
\hline 6.8 & 1063.56 & 2.3 & 0.09 & 0 & 311 & 0.03 & 0.28 & \\
\hline 7.8 & 1063.57 & 2.0 & 0.10 & 113 & 350 & 0.11 & 0.35 & 355 \\
\hline 8.7 & 1063.58 & 2.8 & 0.30 & 74 & 330 & 0.24 & 0.99 & 358 \\
\hline 9.4 & 1063.59 & & 0.22 & 83 & 132 & 0.18 & 0.29 & 385 \\
\hline 10.5 & 1063.60 & 1.7 & 0.33 & 62 & 267 & 0.21 & 0.88 & 418 \\
\hline 10.9 & 1063.60 & & 0.27 & 69 & 396 & 0.19 & 1.07 & 356 \\
\hline 11.5 & 1063.61 & 2.6 & 0.12 & 0 & 542 & 0.01 & 0.65 & \\
\hline 11.7 & 1063.61 & & 0.11 & 0 & 645 & 0.01 & 0.71 & \\
\hline 11.9 & 1063.61 & 2.0 & 0.20 & 62 & 350 & 0.12 & 0.70 & 418 \\
\hline 12.1 & 1063.62 & 2.1 & 0.11 & 0 & 364 & 0.01 & 0.40 & \\
\hline 12.4 & 1063.62 & 2.9 & 0.10 & 0 & 530 & 0.00 & 0.53 & \\
\hline 12.8 & 1063.62 & 2.4 & 0.08 & 88 & 1363 & 0.07 & 1.09 & 423 \\
\hline 13.3 & 1063.63 & 2.0 & 0.09 & 0 & 1133 & 0.01 & 1.02 & \\
\hline 13.6 & 1063.63 & 2.6 & 0.11 & 0 & 982 & 0.01 & 1.08 & \\
\hline 14.2 & 1063.64 & 2.3 & 0.09 & 87 & 1044 & 0.08 & 0.94 & 418 \\
\hline 14.7 & 1063.64 & 3.1 & 0.08 & 96 & 1263 & 0.08 & 1.01 & 373 \\
\hline 15.2 & 1063.65 & 3.2 & 0.05 & 0 & 3420 & 0.01 & 1.71 & \\
\hline 15.6 & 1063.65 & & 0.21 & 69 & 676 & 0.15 & 1.42 & 416 \\
\hline 16.1 & 1063.66 & 3.3 & 0.11 & 0 & 755 & 0.00 & 0.83 & \\
\hline 16.6 & 1063.66 & & 0.16 & 77 & 1594 & 0.12 & 2.55 & 354 \\
\hline 17.0 & 1063.67 & 3.3 & 0.04 & 0 & 3525 & 0.01 & 1.41 & \\
\hline 17.5 & 1063.67 & & 0.09 & 78 & 2867 & 0.08 & 2.58 & 389 \\
\hline 18.4 & 1063.68 & & 0.11 & 0 & 2845 & 0.00 & 3.13 & \\
\hline 18.9 & 1063.68 & 3.7 & 0.01 & 0 & & 0.01 & 2.79 & \\
\hline 19.8 & 1063.69 & 4.2 & 0.03 & 0 & 3500 & 0.03 & 1.05 & \\
\hline 20.3 & 1063.70 & 4.1 & 0.04 & 0 & 2650 & 0.01 & 1.06 & \\
\hline 20.7 & 1063.70 & 4.1 & 0.01 & 261 & & 0.03 & 1.81 & 389 \\
\hline 21.2 & 1063.71 & 3.9 & 0.01 & 0 & 7900 & 0.01 & 0.79 & \\
\hline 21.7 & 1063.71 & 4.4 & 0.08 & 0 & 1288 & 0.00 & 1.03 & \\
\hline 22.1 & 1063.72 & 4.4 & 0.03 & 0 & 3433 & 0.04 & 1.03 & \\
\hline 22.6 & 1063.72 & 3.9 & 0.07 & 0 & 2243 & 0.01 & 1.57 & \\
\hline 22.9 & 1063.72 & 2.5 & 0.07 & 0 & 1200 & 0.01 & 0.84 & \\
\hline 23.1 & 1063.73 & 2.7 & 0.06 & 0 & 1367 & 0.01 & 0.82 & \\
\hline 23.2 & 1063.73 & 2.5 & 0.13 & 0 & 400. & 0.01 & 0.52 & \\
\hline 23.5 & 1063.73 & & 0.35 & 60 & 197 & 0.22 & 0.69 & 414 \\
\hline 24.0 & 1063.74 & & 0.08 & 0 & 1375 & 0.01 & 1.10 & \\
\hline 24.4 & 1063.74 & 2.7 & 0.08 & 0 & 825 & 0.00 & 0.66 & \\
\hline
\end{tabular}

Note: Blank space indicates "not determined." 


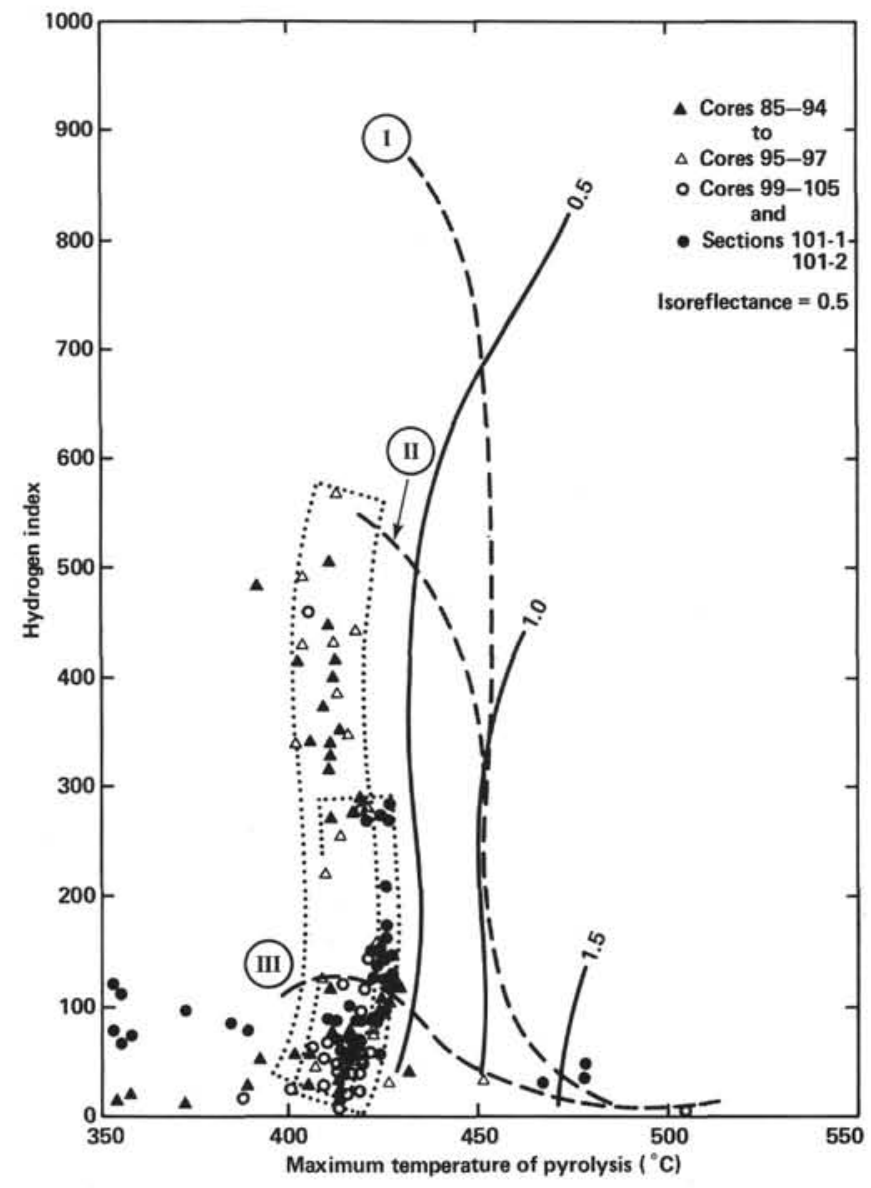

Figure 4. Diagram of hydrogen indices versus pyrolysis peak temperatures.

rials of Types II and III. The area between curves 0.5 and 1.0 defines the "oil window," i.e., the zone where the main formation of liquid hydrocarbons occurs. Beyond curve 1.0 is found the zone for the formation of condensate and wet gas; beyond 2.0 , that of dry gas.

The pyrolysis temperatures (Table 2) measured along Unit 8, i.e., between 940 and $1103 \mathrm{~m}$ below the seafloor, range from 400 to $427^{\circ} \mathrm{C}$ for organic matter with hydrogen indices of 100 and more (Fig. 4). A shifting of some $5^{\circ} \mathrm{C}$ is observed when comparing Core 85 to 97 data (Coniacian-Turonian-Cenomanian) and Core 98 to 105 data (Cenomanian-Albian). This should be explained for the latter both by maturation and by a somewhat larger contribution of recycled organic matter. In any case, the pyrolysis temperatures represent the immature stage of organic matter, before reaching the oil window.

\section{Analysis of Carbon and Organic Matter along a Lithological Sequence, Core 530A-101, Sections 1 and 2}

As mentioned, a single black-shale sequence was first examined. It belongs to Sections 1 and 2 of Core 101. As was true for many black-shale sequences described by the on-board sedimentologists, an olive black laminated and/or burrowed shale overlain by gray burrowed claystone and underlain by pale green burrowed claystone defines the sequence. Short black streaks are observed in both overlying and underlying claystones. They become fewer and farther apart in the adjacent very light gray nannofossil-foraminifer ooze at the bottom and the green marlstone at the top. The latter is overlain by dark gray laminae interbedded with thinner and light gray laminae at the top of the interval sampled.

Some 79 samples were collected along the $38 \mathrm{~cm}$ of the total sequence. The spacing requires a decimal notation for centimeters when the interval of a sample has to be expressed.

\section{Mineral Carbon and Carbonates (Table 1, Fig. 5)}

A range of 5 to $37 \mathrm{wt} . \%$ of calcium carbonate equivalent ( 0.57 to $4.40 \mathrm{wt} . \%$ of mineral carbon) was found along the single black-shale sequence in Core 101 .

When three classes of carbonates-i.e., a poor one ( 0 to $15 \mathrm{wt} . \%$ ), a medium ( 16 to $25 \mathrm{wt} . \%$ ), and a rich one (26 to 35 wt.\%)-are considered, the poor class corresponds to the interval from $530 \mathrm{~A}-101-1,144.4 \mathrm{~cm}$ to $530 \mathrm{~A}-101-2,1.7 \mathrm{~cm}$, i.e., the main black bed. At the top of the interval, Sample 530A-101-1, $143.9 \mathrm{~cm}$, which corresponds to a thin detrital level, must be included in this class. The smallest contents are found at the bottom for Samples 530A-101-1, $148.8 \mathrm{~cm}$, and 530A-101-2, $0.2 \mathrm{~cm}$. The medium class is present on both sides of the black bed, i.e., from Sample 530A-101-1, $137.0 \mathrm{~cm}$ to Sample 530A-101-1, $143.4 \mathrm{~cm}$ for the top part, and between Sample 530A-101-2, $2.2 \mathrm{~cm}$ and Sample 530A$101-2,14.7 \mathrm{~cm}$ at the bottom, and it corresponds to green and green-gray claystones with black streaks. A darker level observed from Sample 530A-101-2, $12.1 \mathrm{~cm}$ to $530 \mathrm{~A}-101-2,13.6 \mathrm{~cm}$ is included. The rich class is again found on either side, i.e., at top of the series for Sample $530 \mathrm{~A}-101-1,136.0 \mathrm{~cm}$ for light green claystone and at the bottom in light green marlstone from Sample 530A$101-2,15.2 \mathrm{~cm}$ to Sample $530 \mathrm{~A}-101-2,22.6 \mathrm{~cm}$. The highest carbonate content $(36.6 \mathrm{wt} . \%)$ is obtained for two basal samples-530A-101-2, $21.7 \mathrm{~cm}$ and $22.1 \mathrm{~cm}$.

The interval analyzed ends with poorer material on both sides-i.e., at the top $10 \mathrm{wt} . \%$ and less for a laminated gray and white claystone (Sample 530A-101-1, $136.0 \mathrm{~cm}$ ), and close to $15 \mathrm{wt} . \%$ for the basal light gray claystone (Sample 530A-101-2, 23-24 cm).

In conclusion, a regular increase in the carbonate content is observed on both sides of the black-shale bed, ranging from 5-15 wt. \% in the black shale to $31-35$ wt. $\%$ in the top and bottom marlstones. A lithologic change easily defines the top of the sequence between Samples 530A-101-1, $136.7 \mathrm{~cm}$ and $137.0 \mathrm{~cm}$, while the bottom boundary cannot be localized more accurately than between 101-2, $18.9 \mathrm{~cm}$ and 101-2., $22.9 \mathrm{~cm}$.

\section{Organic Carbon}

A variation of the organic carbon (OC) content from 0.01 to $3.35 \mathrm{wt}$. \% of total rock is observed along the interval analyzed (Table 1, Fig. 5). The following classes will be considered:

1) Very rich: $>3$ wt. $\%$

2) Rich: $1.01-3.00$ wt. \%

3) Average: 0.51-1.00

4) Low: $<0.50$ 
G. DEROO, J. P. HERBIN, A. Y. HUC

Table 2. Sample depth, carbon, and pyrolysis assay data, Cores 50 to 105, Hole 530A.

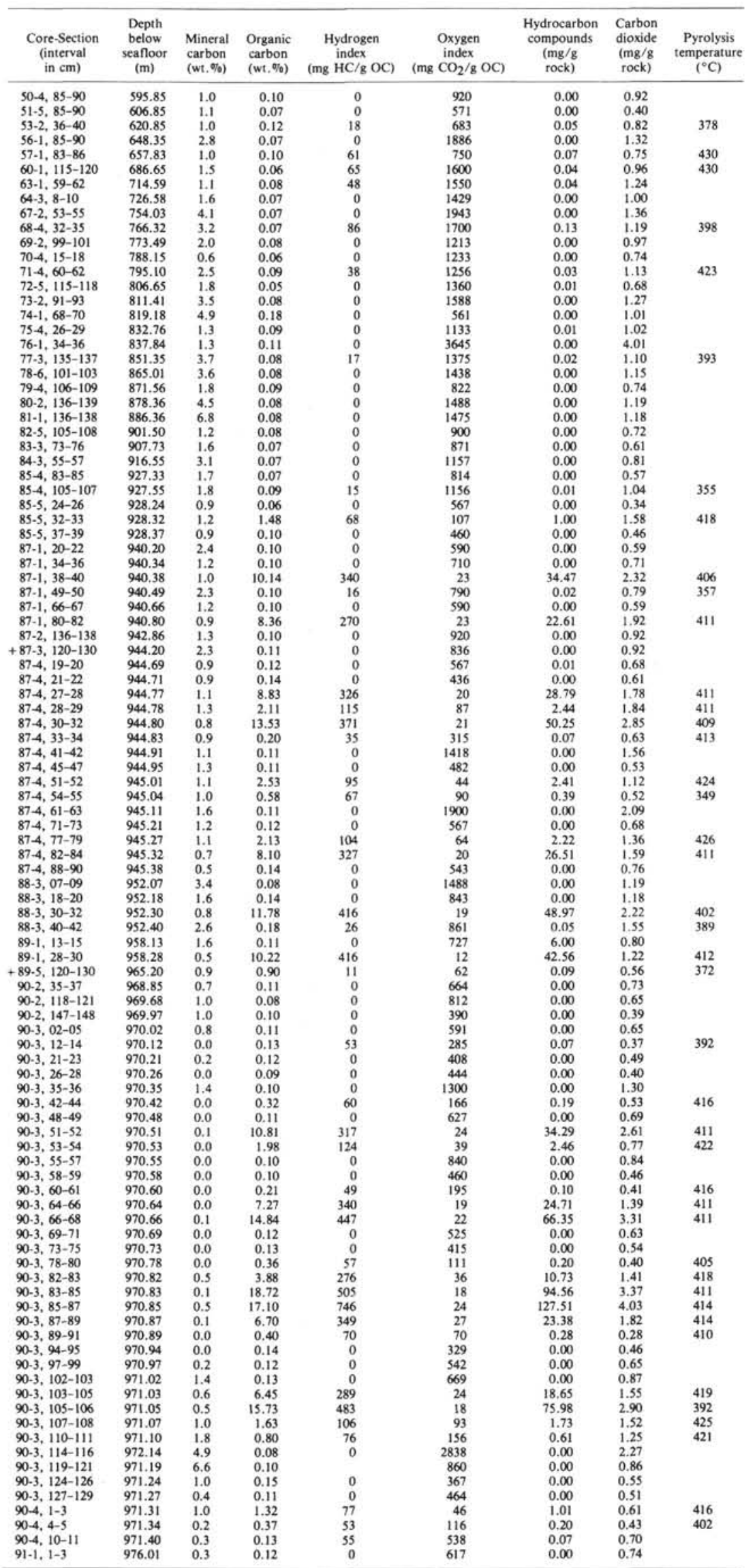


Table 2. (Continued).

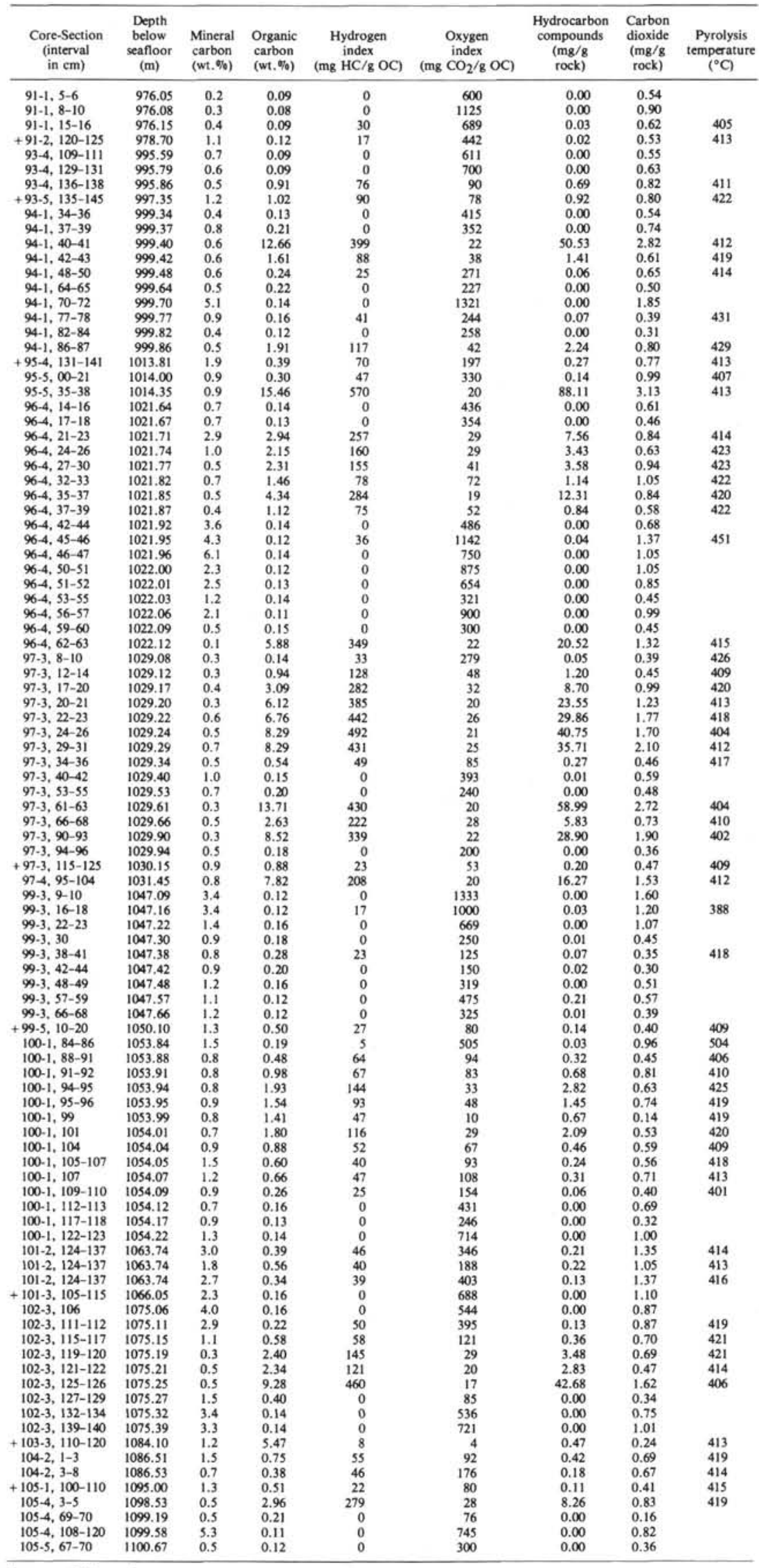

Note $+=$ OGP sample. 
The rich class is found in the main black bed from Samples 530A-101-1, $144.4 \mathrm{~cm}$ to 530A-101-2, $2.2 \mathrm{~cm}$. The finely laminated clays at the top of the sequence (i.e., $530 \mathrm{~A}-101-1,136.0 \mathrm{~cm}$ to $136.7 \mathrm{~cm}$ ) reveal contents close to $1 \mathrm{wt} . \%$. Such contents are also found at the bottom of the black bed for 530A-101-2, 2.8 and $3.1 \mathrm{~cm}$. They are the only data for the average class. On the other hand the low class is present extensively, especially in the 0.21 to $0.35 \mathrm{wt} . \%$ ranges. The latter is found on both sides of the black bed from Samples 530A-101-2, $3.5 \mathrm{~cm}$ to $10.9 \mathrm{~cm}$ at the bottom and from $530 \mathrm{~A}-101-1$, $142.8 \mathrm{~cm}$ to $143.7 \mathrm{~cm}$ at the top, just on top of a thin detrital level. Two discrete beds also belong to this range, i.e., a brownish layer for Sample 530A-101-1, $139.8 \mathrm{~cm}$, and at the bottom some light gray claystone for Sample $530 \mathrm{~A}-101-2,23.5 \mathrm{~cm}$. Poorer data were obtained for Samples 530A-101-2, $18.9 \mathrm{~cm}$ to $21.2 \mathrm{~cm}(0.04 \mathrm{wt} . \%$ and less) amidst one of the intervals where data are not significant ( $0.10 \mathrm{wt} . \%$ and less), i.e., on the top from Samples $530 \mathrm{~A}-101-1,137.0 \mathrm{~cm}$ to $142.2 \mathrm{~cm}$ and on the bottom between Samples 530A-101-2, $12.4 \mathrm{~cm}$ and $24.4 \mathrm{~cm}$.

When the OC distribution is compared to that of carbonate, the poor carbonate content observed for the black shales corresponds to the richer OC contents, while the carbonate-rich green marlstones on both sides reveal the poorest organic material.

\section{Petroleum Potential}

The total hydrocarbons $\left(S_{1}+S_{2}\right.$; Espitalié et al., 1977) expelled during pyrolysis represent the petroleum potential. Since free hydrocarbons $\left(S_{1}\right)$ are sparsely present, only the hydrocarbons issuing from kerogen $\left(S_{2}\right)$ are considered here (Table 1, Fig. 5).

A positive correlation is clearly observed when the vertical distribution of petroleum potentials and organic carbon contents are compared. In the black-shale inter$\mathrm{val}$, the passage from poor potentials (less than $0.5 \mathrm{~kg}$ of hydrocarbons per metric ton of rock) to average potentials $(2.01$ to $5 \mathrm{~kg} / \mathrm{t})$ is progressive, while it is abrupt from average potentials to good potentials (5.01 to 20 $\mathrm{kg} / \mathrm{t}$ ). On both sides, green claystones and marlstones are devoid of any petroleum potential.

\section{Hydrogen Index}

The hydrogen indices $(\mathrm{HI})$ are considered questionable when they are related to an organic carbon content of 0.10 and less. A large proportion of the others (Table 1) depends on the black-shale bed and the adjacent claystones between Samples 530A-101-1, $142.9 \mathrm{~cm}$ and 143.7 $\mathrm{cm}$ at the top, and between Samples 530A-101-2, $2.8 \mathrm{~cm}$ and $4.3 \mathrm{~cm}$ at the bottom. The others correspond, respectively, to the thinly laminated level at the top (530A$101-1,137 \mathrm{~cm}$ ), to the passage from $530 \mathrm{~A}-101-2,8.7 \mathrm{~cm}$ to $10.9 \mathrm{~cm}$, and to a brown level at 530A-101-1, 139.8 $\mathrm{cm}$. Even for the most organic-rich material in the black bed, the $\mathrm{HI}$ range is low (less than 300 ).

\section{Carbon Dioxide}

During Rock-Eval analysis, carbon dioxide issuing from oxygenated compounds of organic matter $\left(S_{3}\right.$ peak) is analyzed (Table 1, Fig. 5). A variation from 0.15 to
$3.13 \mathrm{~kg}$ of carbon dioxide (CD) per metric ton of rock $(\mathrm{kg} / \mathrm{t})$ was observed along the interval analyzed.

When the vertical distribution of CD is considered (Fig. 5), two maxima appear along the base line. One of them $(1.45 \mathrm{~kg} / \mathrm{t})$ corresponds to the most organic-rich sample (Sample 530A-101-1, $147.3 \mathrm{~cm}$ ) in the black, shales. The other is located in the organic-poor material of the green and gray marlstones, with 2.79 to $3.13 \mathrm{~kg} / \mathrm{t}$ for Samples 530A-101-2, $18.4 \mathrm{~cm}$ and $18.9 \mathrm{~cm}$. The first maximum is clearly related to the organic carbon maximum for the black-bed interval, the other corresponds to a very low $\mathrm{OC}$ content.

The negative correlation observed for the $\mathrm{CD}$ and $\mathrm{OC}$ contents can be used to delimit the rhythmic sedimentation in the interval studied here. Thus the base of the organic-poor and carbonate-rich sediments for the bottom member of the sequence is characterized by a maximum of carbon dioxide. Considering the very low content of OC $(0.01 \mathrm{wt} . \%)$ and of hydrogenated compounds encountered at this level, deeply altered organic matter, and thus oxidizing conditions of the environment of deposition, can be inferred.

\section{Oxygen Index}

Oxygen indices will not be examined because their variations duplicate the carbon dioxide variations discussed here (Table 1).

\section{Chloroform Extracts}

A low hydrocarbon content was detected in the three samples selected (Table 3) from the black-shale bed. It represents 15 to $18 \mathrm{wt} . \%$ of the total extract, and the latter represents 0.2 to 0.5 wt.\%o of rock and 1.2 to $1.9 \mathrm{wt} . \%$ of the total OC. As usually found for DSDP material of Cretaceous age, NSO compounds largely predominate (Table 3). Gas chromatography of saturates (Fig. 6A) reveals a large proportion of pristane which suggests a reducing environment. Normal $\mathrm{C}_{15}$ and $n-\mathrm{C}_{17}$ predominate in the $\mathrm{C}_{15}$ to $\mathrm{C}_{35}$ range of $n$-alkanes. A noticeable contribution of polycyclics occurs in the $\mathrm{C}_{27+}$ range of steranes/sterenes and triterpanes/triterpenes as observed elsewhere (Roucaché et al., 1979). A chromatogram of the aromatics (Fig. 6C) shows a predominance of monoaromatics and a large contribution of monoand diaromatics (Castex et al., 1974) in the $C_{15}$ to $C_{20}$ range. All these characteristics are indicative of an immature organic matter of marine origin (Type II), as found for saturates of a marine Toarcian type sample (Fig. 6B).

\section{Nature of the Organic Matter (from pyrolysis results)}

When the diagrams of the hydrogen index (HI) and the oxygen index (OI) (Fig. 7A, B) are compared, the following becomes apparent.

The black-shale bed, from Samples 530A-101-1, $144.4 \mathrm{~cm}$ to $530 \mathrm{~A}-101-2,4.3 \mathrm{~cm}$, reveals plots located in the lower area of the Type I and II evolution paths. Since they correspond to an immature material (pyrolysis temperatures from 421 to $427^{\circ} \mathrm{C}$ ), the relatively low HI (210 to 122) must indicate some retention of hydrocarbons in the mineral matrix during pyrolysis (Espitalié 


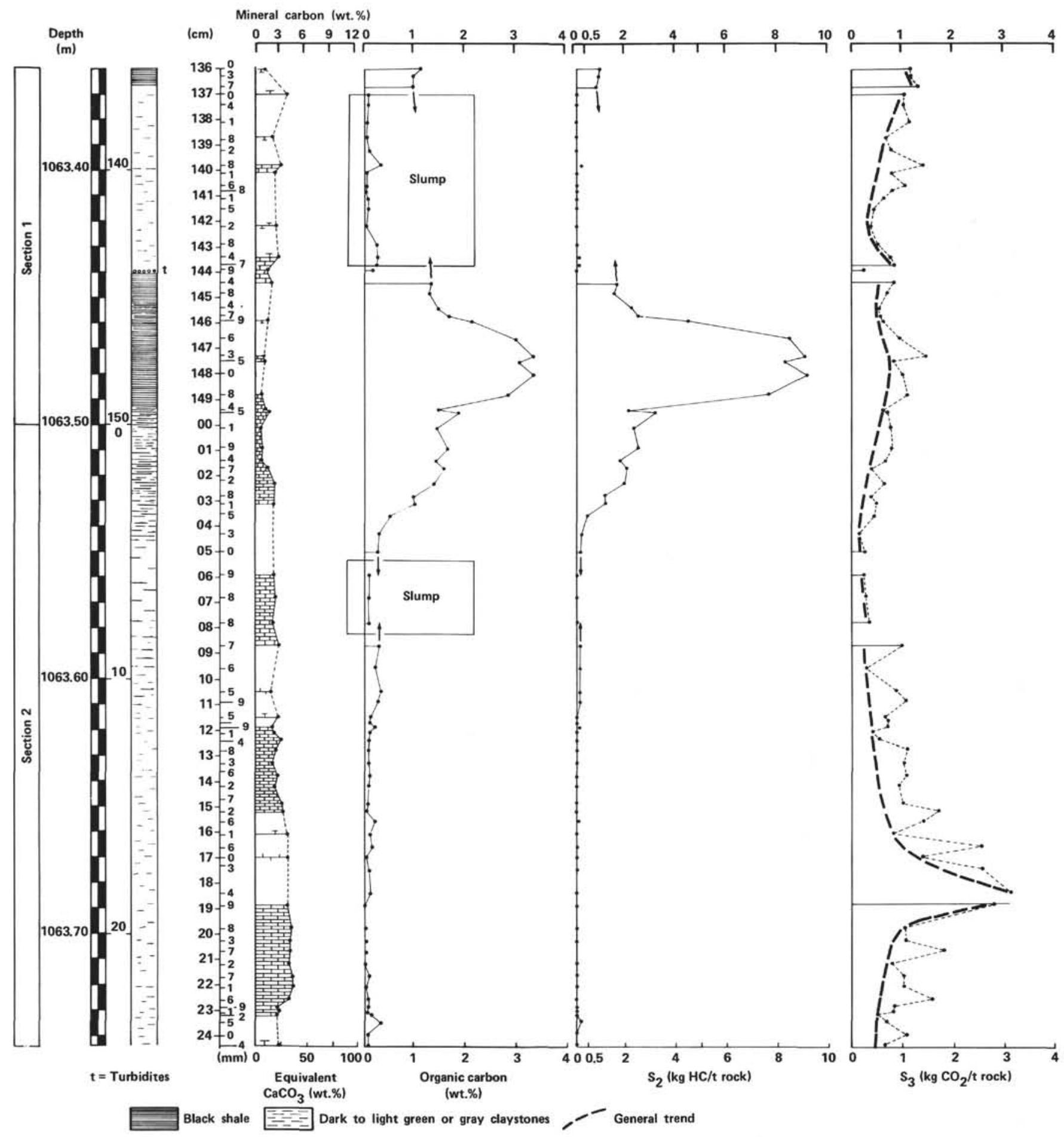

Figure 5. Geochemical $\log$ in Sections 101-1 and 101-2, Hole 530A.

et al., 1980) on the one hand as well as inputs of detrital organic matter into the autochthonous marine ones on the other hand. The detrital inputs may occur from more-or-less altered recycled Type III material. Such an altered material with a zero $\mathrm{HI}$ is found just on top of the black bed. It corresponds to a thin coarse clastic level for Sample 530A-101-1, $143.9 \mathrm{~cm}$. The absence of any HI suggests an overmaturation and thus a recycling, and the low OI (106) suggests reduced environments for pri- mary and secondary depositions. The contribution of overmature material is controlled by the low $\mathrm{O} / \mathrm{C}$ ratio observed for the kerogen concentrate at the interval 530A-97-4, 95 to $104 \mathrm{~cm}$ (Table 4), implying a very advanced stage of maturation. The path followed on the HI versus OI diagram (Fig. 7A) from the relatively high $\mathrm{H}$ index in black-shale to the zero index for the detrital level-i.e., from Samples 530A-101-1, $146.6 \mathrm{~cm}$ to $143.9 \mathrm{~cm}$-is representative of a progressive enrichment 
Table 3. Composition of chloroform extracts, Hole 530A.

\begin{tabular}{|c|c|c|c|c|c|c|c|}
\hline \multirow[b]{3}{*}{$\begin{array}{c}\text { Sample } \\
\text { (level in } \mathrm{cm} \text { ) }\end{array}$} & \multirow{3}{*}{$\begin{array}{l}\text { Sub- } \\
\text { bottom } \\
\text { depth } \\
\text { (m) }\end{array}$} & \multirow{3}{*}{$\begin{array}{c}\mathrm{HC} \mathrm{C}_{13} \\
\text { Extract } \\
\text { (wt. mg) }\end{array}$} & \multicolumn{2}{|c|}{ Extract related } & \multicolumn{3}{|c|}{$\begin{array}{l}\text { Thin-layer chromatography } \\
\text { fractionation }\end{array}$} \\
\hline & & & \multirow[b]{2}{*}{$\begin{array}{l}\text { To rock } \\
\text { (wt. \%) }\end{array}$} & \multirow[b]{2}{*}{$\begin{array}{c}\text { To OC } \\
(\%)\end{array}$} & \multirow[b]{2}{*}{$\begin{array}{l}\text { NSO } \\
\text { compounds }\end{array}$} & \multicolumn{2}{|c|}{ Hydrocarbon fraction } \\
\hline & & & & & & $\begin{array}{l}\text { Aromatic } \\
(\%)\end{array}$ & $\begin{array}{l}\text { Saturated } \\
(\%)\end{array}$ \\
\hline $101-1,144$ & 1063.44 & 1.45 & 0.02 & 1.9 & 82 & 10 & 8 \\
\hline $101-1,146-147$ & 1063.46 & 3.10 & 0.05 & 1.2 & 85 & 10 & 5 \\
\hline $101-1,149$ to & 1063.49 & 2.60 & 0.04 & 1.5 & 82 & 13 & 5 \\
\hline
\end{tabular}
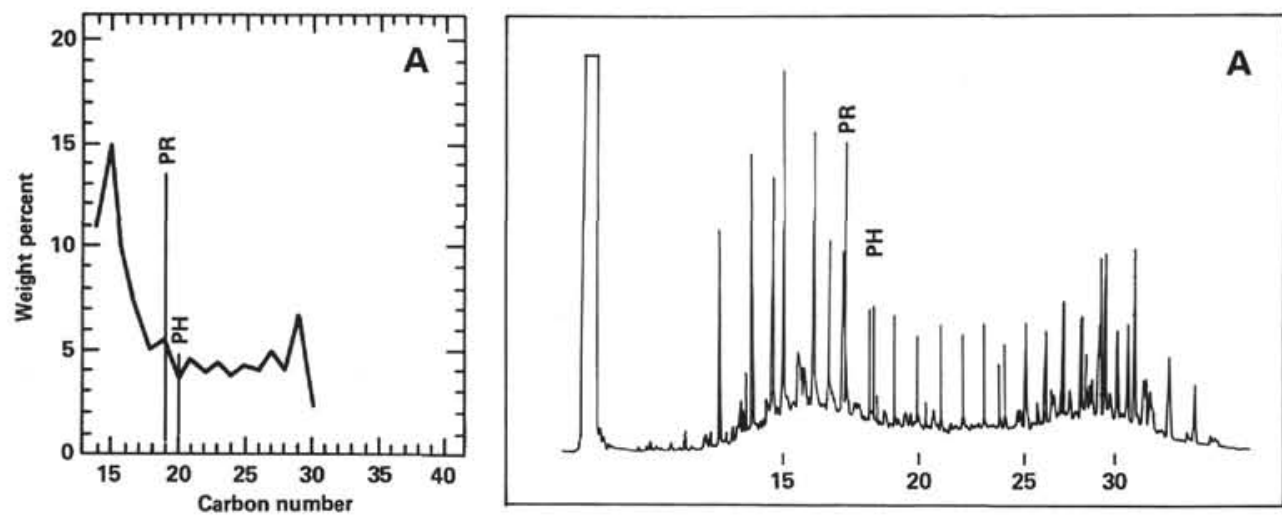

PR $=$ Pristane $\quad$ PH $=$ Phytane
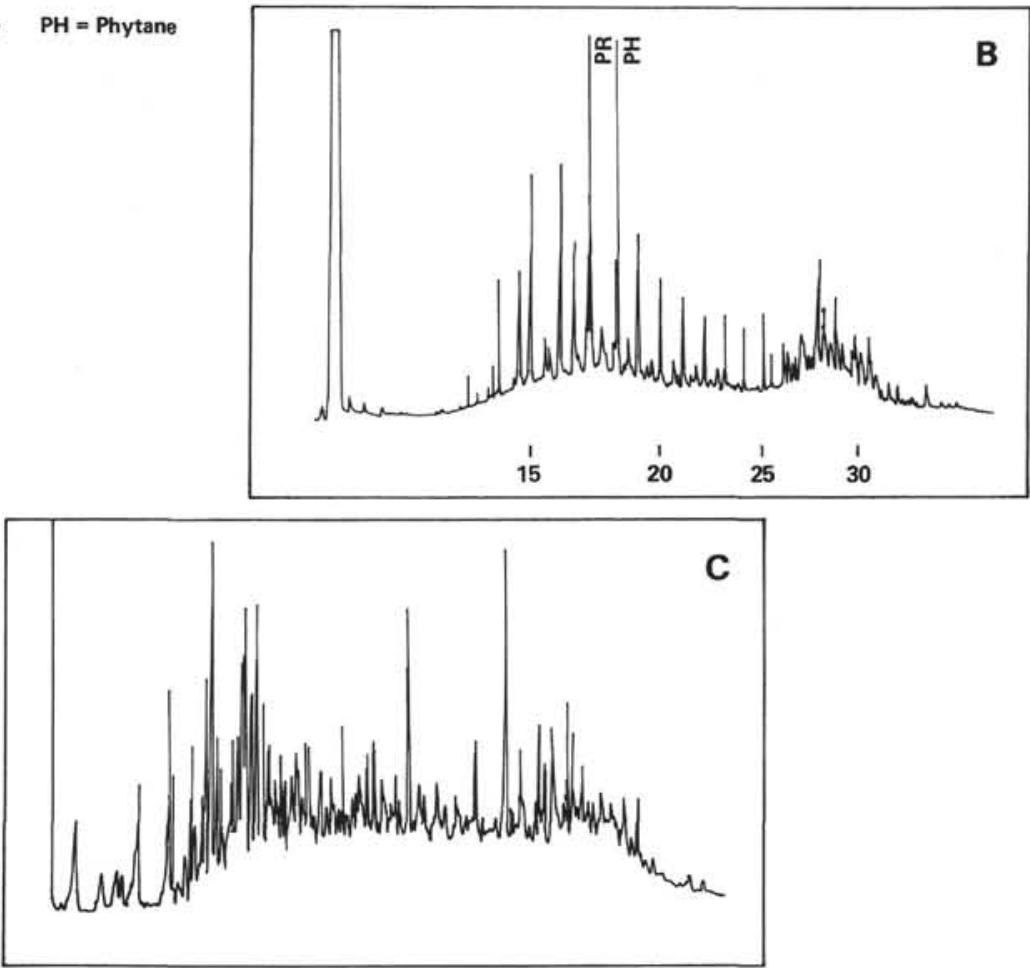

Figure 6. Gas chromatography of saturated fraction: A. Sample 530,101-1, $146 \mathrm{~cm}$; B. Fecocourt outcrop, France, Toarcian; C. Gas chromatography of aromatic fraction: Sample 530-101-1, $146 \mathrm{~cm}$.

of detrital and reworked organic matter compared to the marine component. A symmetric trend is observed (Fig. 7B) from Sample 530A-101-1, $147.3 \mathrm{~cm}$ to $530 \mathrm{~A}$ $101-2,4.3 \mathrm{~cm}$ in the underlying claystones.

The gray and green claystones on both sides of the black-shale bed reveal high $\mathrm{O}$ indices ( 250 and more), generally related to low or zero $\mathrm{H}$ indices. The poor organic matter contents suggest oxygenated environments. The trend of $\mathrm{H}$ indices ranging from low to zero reflects the range of the various mixtures of the two components, i.e., detrital organic matter on the one hand and wholly oxidized organic matter on the other. That dual- 

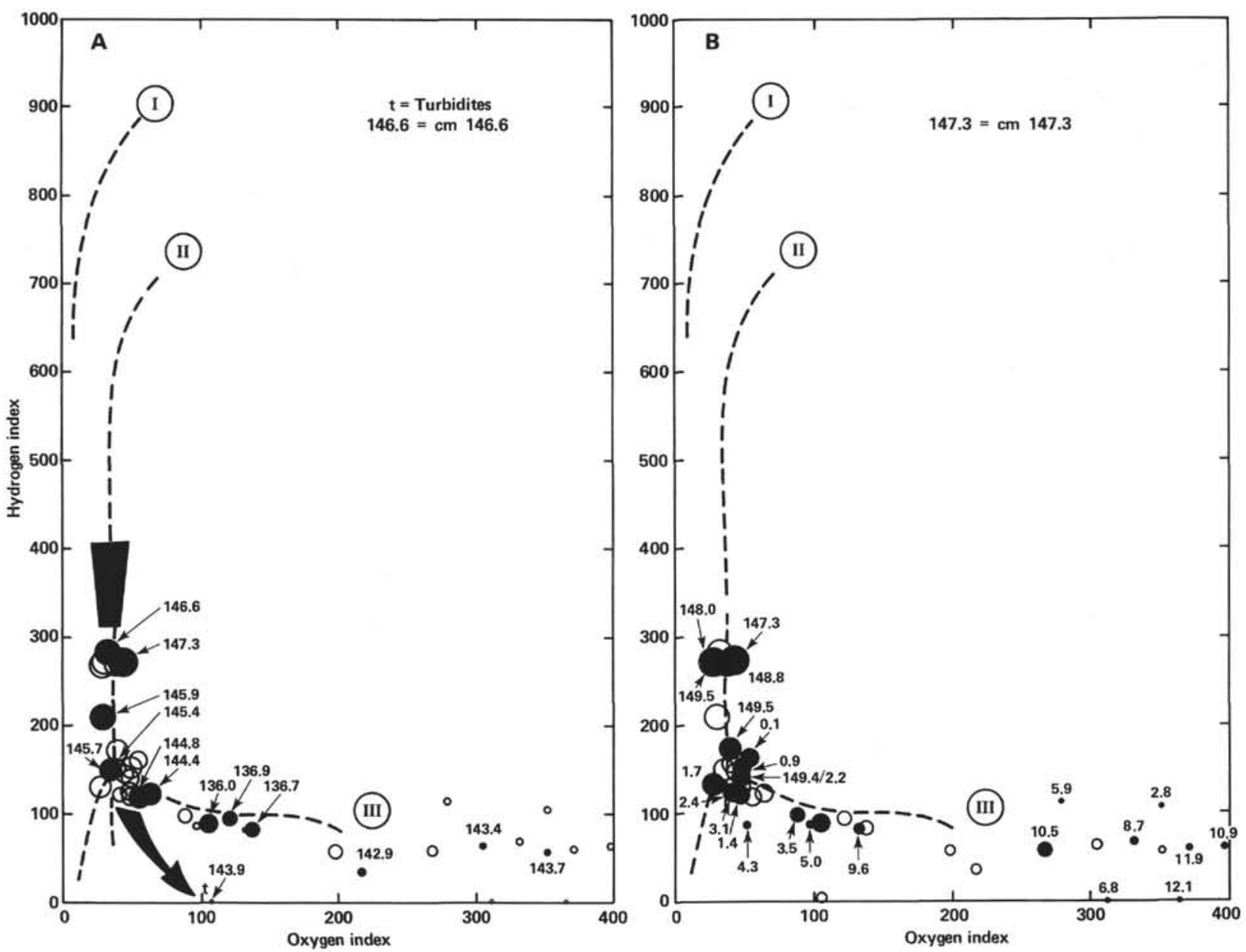

Figure 7. Diagram of hydrogen index versus oxygen index. A. interval 101-1, 136 to $147 \mathrm{~cm}$; B. interval $101-1,147 \mathrm{~cm}$ to $101-2,24 \mathrm{~cm}$.

Table 4. Elemental composition and ash content of kerogen concentrates, Hole 530A.

\begin{tabular}{|c|c|c|c|c|c|c|c|c|c|c|c|c|}
\hline \multirow{3}{*}{$\begin{array}{c}\text { Sample } \\
\text { (interval in } \mathrm{cm} \text { ) }\end{array}$} & \multirow{3}{*}{$\begin{array}{l}\text { Sub- } \\
\text { bottom } \\
\text { depth } \\
\text { (m) }\end{array}$} & \multicolumn{2}{|c|}{ Pyrolysis } & \multicolumn{9}{|c|}{ Elemental analysis } \\
\hline & & \multirow{2}{*}{$\begin{array}{l}\text { Hydrogen } \\
\text { index }\end{array}$} & \multirow{2}{*}{$\begin{array}{l}\text { Oxygen } \\
\text { index }\end{array}$} & \multicolumn{6}{|c|}{ Ash-free basis (wt.\%) } & \multirow{2}{*}{$\frac{\text { Ashes }}{(\text { wt.\%) }}$} & \multicolumn{2}{|c|}{ Atomic } \\
\hline & & & & c & H & $\mathrm{N}$ & 0 & s & $\mathrm{Fe}$ & & $\mathrm{H} / \mathrm{C}$ & $\mathrm{O} / \mathrm{C}$ \\
\hline & & & 33 & & & 0.39 & & & & & $\ldots$ & 6 \\
\hline $\begin{array}{l}95-5,35-48 \\
\text { and } 95, \mathrm{CC}\end{array}$ & 101 & 570 & 20 & 54 & 5.32 & 1.71 & 0 & 16.40 & 10. & 3.56 & 2 & 0.12 \\
\hline $97-4,95-104$ & 1031.45 & 208 & 20 & 57.81 & 3.66 & 1.31 & 5.70 & 11.90 & 11.40 & 8.32 & 0.76 & 0.07 \\
\hline
\end{tabular}

ity of the organic matter goes with a dual composition for the lithology. The detrital organic matter corresponds to the black streaks while the largely oxidized and thus undifferentiated organic matter is related to the bulk material, i.e., the claystones. When the black-streak contribution decreases along the claystones and marlstones, the $\mathrm{H}$ indices decrease to zero and the $\mathrm{O}$ indices become higher. Concurrently, an impoverishment of the OC content resulting from alteration is observed.

Dark gray and light gray laminae at the top of the interval analyzed $(530 \mathrm{~A}-101-1,136 \mathrm{~cm})$ represent an alternation of reduced and oxidized materials. The $\mathrm{H}$ indices (85 to 98 ) imply a contribution of detrital and primarily reduced organic matter issuing from the dark laminae. The $O$ indices (105 to 136) imply a contribution of undifferentiated and oxidized organic matter found in the light-colored laminae.

\section{Nature of the Organic Matter (from kerogen results)}

A check was made for the kerogen concentrates of two main lithologic facies. Two samples were obtained from Core 95; i.e., a green claystone (Sample 530A-95-5, 0-21 cm) and a black shale (Sample 530A-95-5, 35-48 cm, plus 530A-95, CC). Another black-shale bed was sampled in Core 97 (Sample 530A-97-4, 95-104 cm). Elemental analysis (Table 4) was performed on the three kerogen concentrates. Data for the green claystone sample cannot be considered because pyrite represents some 80 percent of the preparation! For the other two samples from black shale, the difference observed between the $\mathrm{H}$ indices remains when their kerogen $\mathrm{H} / \mathrm{C}$ ratios are considered. The kerogen from Section $95-5$ is placed in a Van Krevelen diagram (Tissot et al., 1974) just beneath the Type II reference path. It indicates a large propor- 
tion of Type I or II marine organic matter and a low stage of maturation. The kerogen from Section $97-4$ is placed just above the humic-coal area at an advanced stage of maturation. The latter characteristic supposes a large contribution of recycled and overmature organic matter (residual material; Tissot et al., 1979) mixed with some marine materials.

When optical examination under natural light is used, the kerogen in black-shale samples from Core 95 (Table 5) reveals amorphous organic matter with a cloud-like texture for the bulk of the preparation. For the sample of green claystone in the same core, both amorphous organic matter with a granulous texture and black-coal debris are the main components ( 45 and $35 \%$ ). Pyrite is abundant ( $15 \%$ and more) as was found from elemental analysis. Humic coaly material (Type III) makes up the bulk of the green claystone preparation and marine organic matter (Type II) the bulk of the black-shale preparation. Thermal alteration indices $(\mathrm{TAI} \pm 2)$ correspond to an immature material.

\section{Characterization of the Previous Sequence (Core 101, Sections 1 and 2)}

The shipboard report notes that since many structures such as graded silt laminae, very low-amplitude ripple cross-lamination, and fine indistinct continuous laminae were observed in many black-shale beds, and since accumulation of organic matter seems to be associated with turbidite processes, the issue was whether the black shales were actually organic-rich turbidites.

Some answers can be proposed here. Discontinuities observed along the $\mathrm{OC}$ vertical distribution are indicative of sedimentation disturbances (Fig. 5). A major change in the $\mathrm{OC}$ content is observed at both ends of interval 530A-101-1, 137 to $144 \mathrm{~cm}$. The upper one is between 136.7 and $137.0 \mathrm{~cm}$, where the $\mathrm{OC}$ decreases from 0.96 to $0.08 \mathrm{wt} . \%$, and the bottom one is between 143.9 and $144.4 \mathrm{~cm}$, where the OC increases from 0.16 to 1.34 wt. \%. Abrupt changes are, therefore, assigned to downslope deposition slumping of the light-green claystones which disturb the black-shale bed. Another, but minor, change attributed to downslope movement is observed just below the black-shale bed between Samples 530A$101-2,5.0$ and $8.7 \mathrm{~cm}$, where the OC content decreases from 0.27 to $0.09 \mathrm{wt} . \%$ and less.

For the interval studied, the lithological sequence begins with carbonate-rich material in which the lowest organic carbon content is related to the highest carbondioxide content (530A-101-2, $18.4 \mathrm{~cm}$ ). Three members can then be characterized along this sequence, from bottom to top, as follows:
1) A lower member, where the organic matter is oxidized and a few black streaks of detrital organic matter are interbedded. This ends at $530 \mathrm{~A}-101-2,3.5 \mathrm{~cm}$ with an enrichment of both black streaks and OC content ( $0.50 \mathrm{wt} . \%)$.

2) An intermediate member, which corresponds to the olive-black and black-shale bed. Detrital organic matter is present throughout but mixed with autochthonous marine organic matter. Reduced environmental conditions prevail. In this member, the symmetrical distribution of organic-carbon content and petroleum-potential on both sides of a maximum rules out any proximal turbiditic episode inside the black-shale bed. Nevertheless, a slump localized along the interval between 530A-101-1, $137.0 \mathrm{~cm}$ and $143.7 \mathrm{~cm}$ disturbs the sedimentation just after the deposition of a thin coarsegrained turbiditic level at $530 \mathrm{~A}-101-1,143.9 \mathrm{~cm}$. The intermediate member was probably formed after the slump deposit.

3) An upper member begins just above the slump. It is sampled only along interval $530 \mathrm{~A}-101-1,136 \mathrm{~cm}$. This level of thin laminae is preferentially placed in a member distinct from the intermediate one because oxidized organic matter is extensively present. However the lack of bioturbation suggests an environment devoid of benthic life and thus poorly oxygenated. Therefore, the dark laminae of this level represent undisturbed equivalents of the detrital black streaks interbedded in the gray and green claystones of the lower member.

In summary, the vertical distribution of organic carbon and pyrolysis parameters for the organic matter serve to characterize the successive members of the black-shale sequence studied. It begins with a carbonate-rich and organic-poor member where oxidized organic matter prevails and where some detrital organic matter occurs. An intermediate black member follows where the detrital and recycled organic matter is largely associated with marine organic matter. Sedimentation in these two members is disturbed by a slump. The upper slump overlies a thin detrital level which must correspond to a coarsegrained turbidite. Other proximal turbidites were not detected. Just above the upper slump, oxidized and detrital organic matter prevails, defining the upper member of the sequence.

\section{Characterization of Unit 8 through the Sequences Analyzed}

Since DSDP sample spacing usually is larger than the one used for the sequence in Core 101, Sections 1 and 2, the question is whether the parameters used to delimit

Table 5. Optical examination and composition of kerogen concentrates, Hole 530A.

\begin{tabular}{|c|c|c|c|c|c|c|c|c|}
\hline \multirow[b]{2}{*}{ Sample } & \multicolumn{2}{|c|}{$\begin{array}{c}\text { Amorphous } \\
\text { organic matter }\end{array}$} & \multirow{2}{*}{$\begin{array}{c}\text { Black } \\
\text { coal } \\
\text { debris }\end{array}$} & \multirow{2}{*}{$\begin{array}{l}\text { Ligneous } \\
\text { debris }\end{array}$} & \multirow[b]{2}{*}{ Spores } & \multirow[b]{2}{*}{ Pyrite } & \multirow{2}{*}{$\begin{array}{l}\text { Thermal } \\
\text { alteration } \\
\text { index }\end{array}$} & \multirow{2}{*}{$\begin{array}{c}\text { Main } \\
\text { organic } \\
\text { facies }\end{array}$} \\
\hline & Granulous & Cloudy & & & & & & \\
\hline $\begin{array}{l}95-5,0-21 \\
\text { (green } \\
\text { claystone) }\end{array}$ & 45 & & 35 & 4 & 1 & 15 & 2 to $2^{+}$ & Type III \\
\hline $\begin{array}{l}95-5,35-48 \text {, and } \\
95, \text { CC (black } \\
\text { shale) }\end{array}$ & & 80 & 10 & 2.5 & 0.5 & 7 & 1 to $2^{-}$ & Type II \\
\hline
\end{tabular}


that sequence can be applied to delimit and characterize all the sequences and related lithologic units.

The boundary at both ends of a sequence can be effectively defined from the pyrolysis data as being the point where the richest carbon-dioxide content $\left(\mathrm{S}_{3}\right)$ is associated with poor hydrocarbon content $\left(\mathrm{S}_{2}\right)$. Since these data are usually related to a low organic-carbon content, the boundaries can also be defined by the richest oxygen index associated with a low hydrogen index. The black bed of a sequence is at the point where the maximum hydrocarbon content $\left(\mathrm{S}_{2}\right)$ is reached. Since the latter generally correlates with a rich organic content, the point can also be defined by the richest hydrogen index of the sequence related to a low oxygen index. The hydrogen index thus defined will be designated here as the "culmination" of each black bed and its sequence.

The method was first applied to a bundle of black beds in Core 530A-90. Along an interval of $1.05 \mathrm{~m}$, six consecutive culmination sequences can be recognized (Fig. 8). Five of them include a black bed. From top to bottom the boundaries based on organic-carbon and pyrolysis data are found at $35,48,55,69-73,97-102$, and $114 \mathrm{~cm}$ and at $10 \mathrm{~cm}$ in the core catcher. A culmination of the hydrogen index (HI) related to a low oxygen index (OI) clearly appears for each sequence on the $\mathrm{HI}$ versus OI diagram in Figure 8. (See Table 6.) The various culminations observed represent four different types ( $a$ to $d$ ) and are characterized as follows:
Type a: Predominantly detrital organic matter of continental origin located at the extremities of the bundle: Samples 530A-90-3, $42 \mathrm{~cm}$ and 90,CC (1 cm);

Intermediate type $b$ : Occurring in the interval 530A90-3, 48-55 cm at Sample 530A-90-3, $51 \mathrm{~cm}$, where marine detrital and organic matter are associated;

Type c: Marine organic matter predominates over detrital in two sequences, at 530A-90-3, 66 and $105 \mathrm{~cm}$;

Type d: Typical marine organic matter enriched with aliphatic compounds, found at 530A-90-3, $85 \mathrm{~cm}$. Such rich-aliphatic organic matter suggests persistent anaerobic conditions.

Over the total interval, a symmetrical distribution of culminations appears, showing an overall culmination for the entire "bundle" in Sample 530A-90-3, $85 \mathrm{~cm}$. This distribution repeats on a larger scale the cyclicity observed in each elemental sequence. A cyclic alternation of marine and detrital organic matter on the scale of a sequence is superimposed on a cyclic variation in the balance of marine and detrital organic matter on the scale of a set of sequences.

On a larger scale of several sets of sequences, a supplementary rhythm is suspected, as is the case for the top of Unit 8 along the $30 \mathrm{~m}$ of Cores 90 to 85 (Fig. 9). When the culminations of the hydrogen index for each set of black beds are considered, a regular decrease upward appears from Core 90 to Core 85 . The detrital organic matter progressively replaces the marine organic

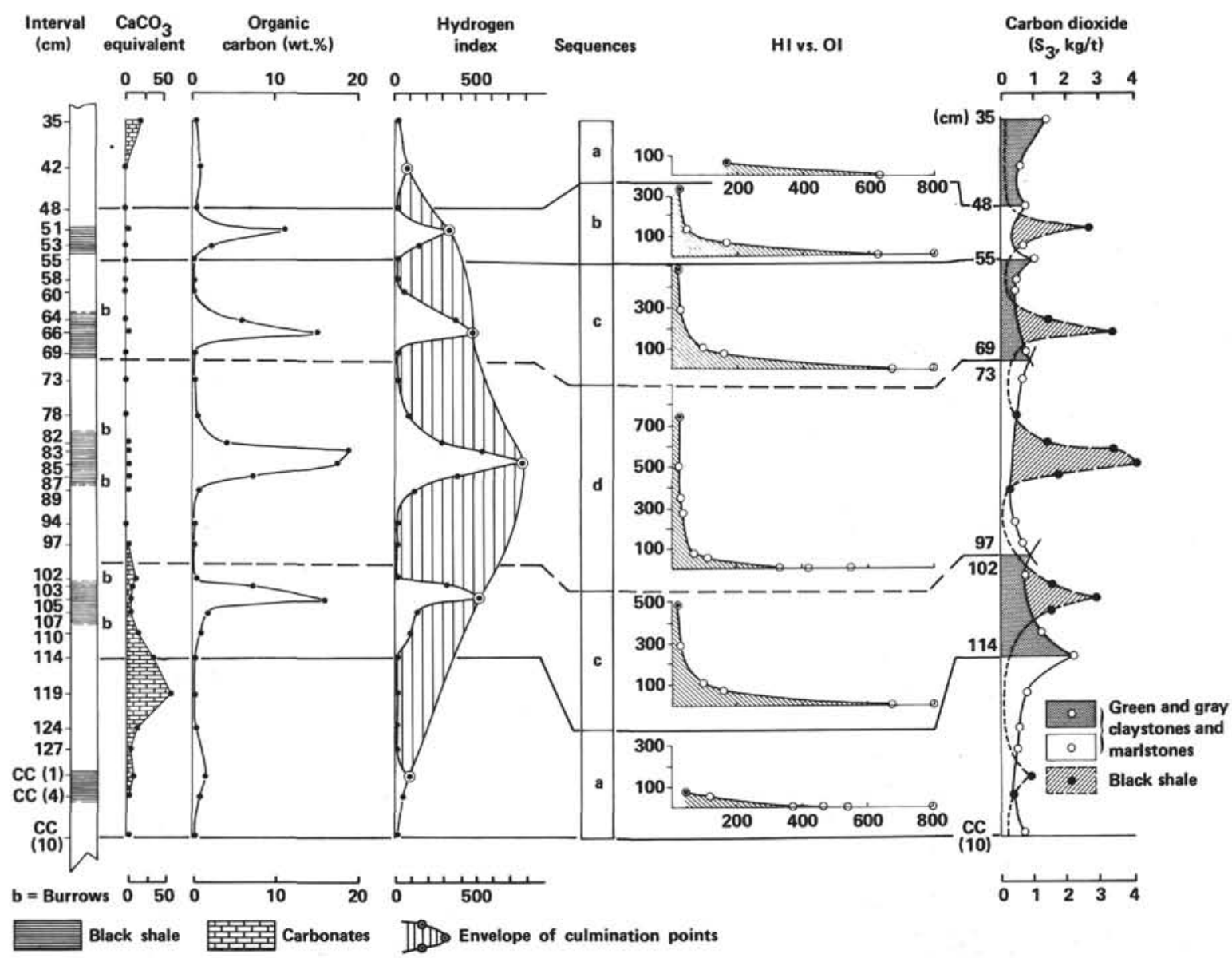

Figure 8. Geochemical $\log$ for a bundle of black shale beds in Section 90-3, Hole 530A. 


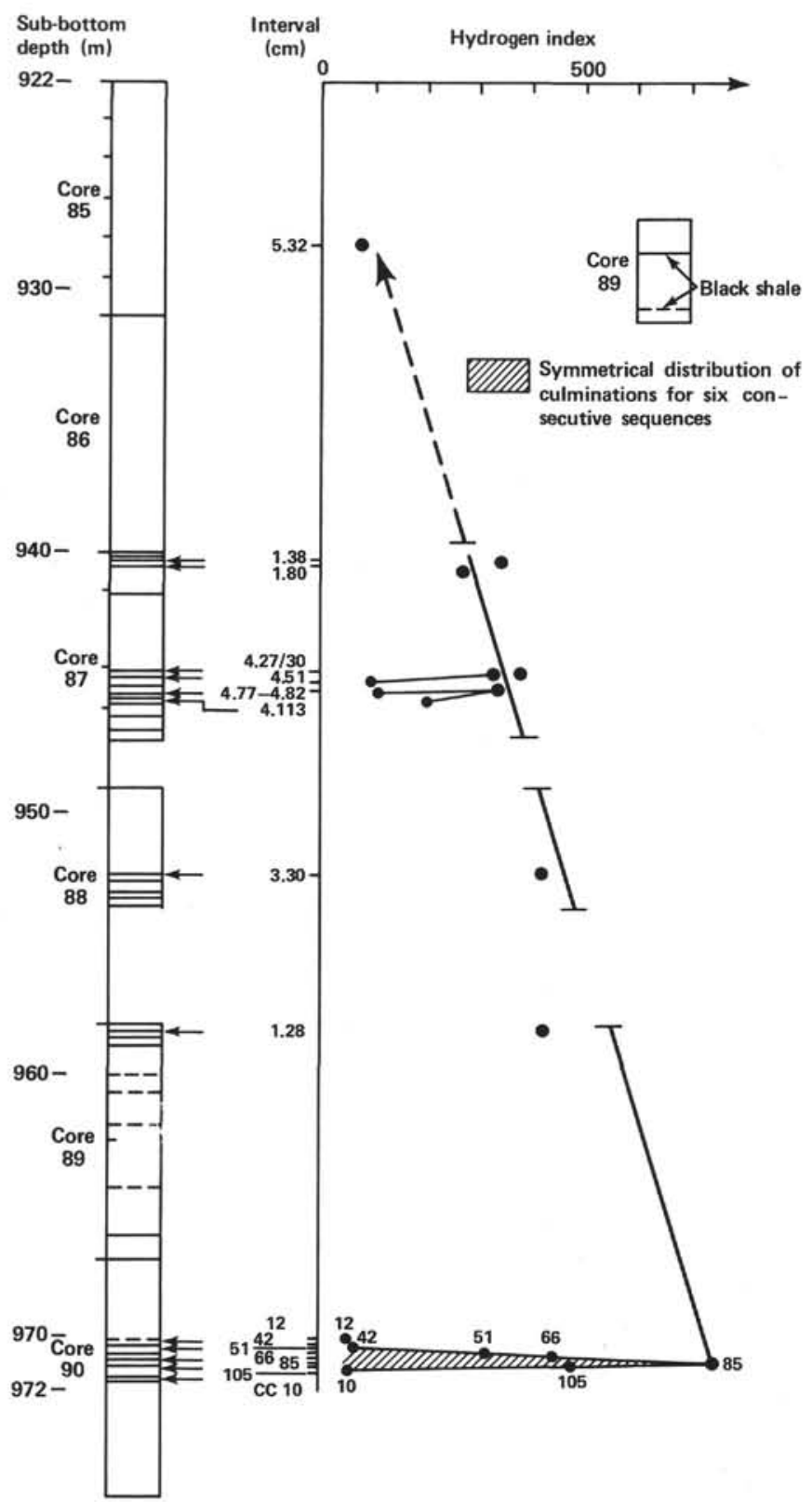

Figure 9. Culminations of depth versus hydrogen index in black shales on both sides of Unit 7 and Unit 8 boundary.

matter and in turn is replaced by oxidized materials devoid of organic matter in Core 85. Therefore, the last organic-rich level is reached at the base of Unit 7, Sample $530 \mathrm{~A}-85-5,32 \mathrm{~cm}$. The trend indicates a general regression from reduced environments toward oxidized ones.

In the classic progradational submarine fan sequence grading from basinal Unit 8 to thick upper fan channel sediments in Unit 6 (Stow, this volume), the variation observed in the organic matter corresponds to the transition from the basin deposits of Unit 8 to the fan-lobe and channel sediments of Unit 7.

To consider the whole $163 \mathrm{~m}$ of Unit 8, 45 beds and sequences were analyzed (Table 6). The distribution of the black-shale bed culminations falls into five hydro-
Table 6. Hydrogen index culminations in black shale sequences, grouped by culmination type. (interval in $\mathrm{cm}$ )

\begin{tabular}{|c|c|c|c|c|c|}
\hline \multirow{4}{*}{$\begin{array}{c}\text { Bed or } \\
\text { sequence } \\
\text { (interval in } \mathrm{cm} \text { ) }\end{array}$} & \multicolumn{5}{|c|}{ Hydrogen index } \\
\hline & $<50$ & $50-100$ & $101-300$ & $301-700$ & $>700$ \\
\hline & \multicolumn{5}{|c|}{ Culmination type } \\
\hline & a & & b & c & d \\
\hline $85-5,24-39$ & & $32-33$ & & & \\
\hline $87-1,20-50$ & & & & $38-40$ & \\
\hline $87-1,66-82$ & & & $80-82$ & & \\
\hline $87-4,19-42$ & & & & $27-28$ & \\
\hline $87-4,19-42$ & & & & $30-32$ & \\
\hline $87-4,42-63$ & & $51-52$ & & & \\
\hline $87-4,63-90$ & & & $77-79$ & $82-84$ & \\
\hline 87.4 & & & 113 & & \\
\hline $88-3,7-42$ & & & & $30-32$ & \\
\hline $89-1,13-28$ & & & & 28 & \\
\hline $90-3,35-48$ & & $42-44$ & & & \\
\hline $90-3,48-55$ & & & $53-54$ & & \\
\hline $90-3,55-69$ & & & & $66-68$ & \\
\hline $90-3,73-97$ & & & & & $85-87$ \\
\hline $90-3,102-114$ & & & & $105-106$ & \\
\hline $90-3,114-130$ & & & & & \\
\hline and $\mathrm{CC}$ to & & CC (1-3) & & & \\
\hline $93-5^{\mathrm{a}}$ & & $135-145$ & & & \\
\hline $94-1,34-72$ & & & & $40-41$ & \\
\hline $94-1,72-87$ & & & $86-87$ & & \\
\hline $95-4^{\mathrm{a}}$ & & $|31-14|$ & & & \\
\hline $95-5,20-48$ & & & & $35-48$ & \\
\hline $96-4,14-46$ & & 32 & $21,24,27$ & 35,39 & \\
\hline $96-4,46-63$ & & & & $62-63$ & \\
\hline $96-6$ & & 38 & & & \\
\hline $97-3,8-42$ & & & 17 & 20 to 31 & \\
\hline $97-3,42-68$ & & & & $61-63$ & \\
\hline $97-3,90-96$ & & & & $90-93$ & \\
\hline $97-3^{\mathrm{a}}$ & $115-125$ & & & & \\
\hline $97-4$ & & & & $56-57$ & \\
\hline $97-4,95-104$ & & & $95-104$ & & \\
\hline $97, \mathrm{CC}$ & & & & $\mathrm{CC}$ & \\
\hline $98-3$ & & & & $92-93$ & \\
\hline $99-5^{\mathrm{a}}$ & $10-20$ & & & & \\
\hline $100-1$ & & & $99-100$ & & \\
\hline $100-1,84-123$ & $99,104,110$ & 91,95 & 94,101 & & \\
\hline $\begin{array}{c}101-1,137-150 \\
\text { to }\end{array}$ & & & 144 to 150 & & \\
\hline $101-2,1-18$ & & & 0 to 3 & & \\
\hline $102-3,106-140$ & & & 119,121 & 126 & \\
\hline $103-3^{\mathrm{a}}$ & $110-120$ & & & & \\
\hline $103-4$ & & & & $85-86$ & \\
\hline $104-3$ & & & & $0-1$ & \\
\hline $105-1^{\mathrm{a}}$ & $100-110$ & & & & \\
\hline $105-2$ & & & & $139-140$ & \\
\hline $105-4,3-120$ & & & $3-5$ & & \\
\hline
\end{tabular}

gen-index classes (Fig. 10) along three stratigraphic subdivisions of Unit 8, i.e., the lower part of the Coniacian (Cores 85 to 94), the lower Turonian to Upper Cenomanian (Cores 95 to 97), and the Lower Cenomanian to Upper Albian (Cores 98 to 105), as follows:

During the early period (the Albian to Cenomanian) most of the culminations belong either to the lowest class ( 0 to 5 ) or to the medium one (101 to 300 ). This distribution is indicative of detrital and allochthonous organic matter. The reverse was observed for the Cenomanian-Turonian and the Coniacian periods. Most of the culminations belong to the medium class (101 to 300$)$ and a higher one (301 to 700 ), which implies autochthonous marine organic matter. The poorest class is present for the Cenomanian-Turonian period and the richest is present only for the Coniacian. When the HI versus OI plots are considered for the whole of Unit 8, similar patterns are found for the two later periods (Fig. 11 ) where marine and detrital organic matter are associ- 

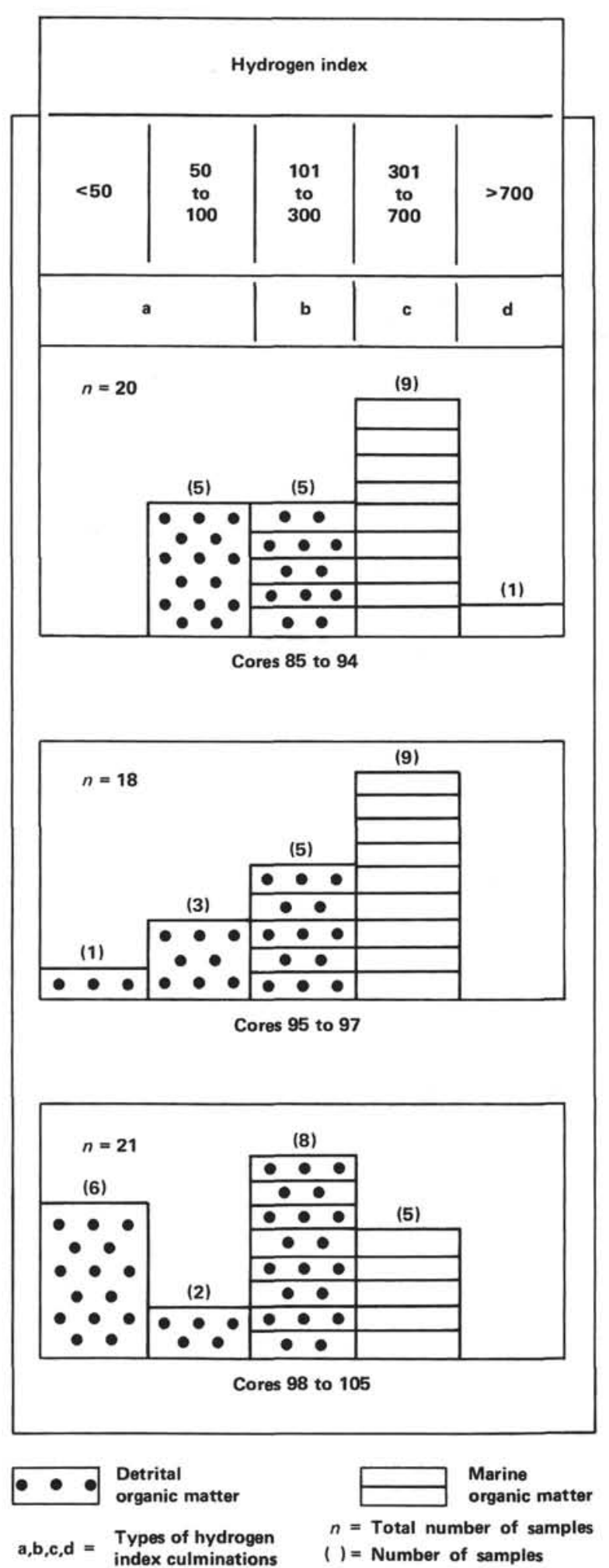

Figure 10. Distribution of hydrogen-index culminations in black-shale beds in lithologic Unit 8.

ated. For the earlier period most of plots depend on a low HI related to a high OI, which in turn is mainly the result of detrital organic material.

More accurate observations and comparisons on the scale of the whole unit would require a more detailed sampling. Consequently several questions, including the following, cannot be answered by the present study: Do the richest black shales occur in the Coniacian? Is the low sedimentation rate for the Cenomanian-to-Turonian period correlative- or not-with a large number of organic-rich black beds? Does a large-scale rhythmic sedimentation prevail throughout the whole of Unit 8 ?

\section{v. Characterization of Organic Matter in the Other Units of Cretaceous Age (Units 5 to 7)}

For all Cretaceous units other than Unit 8 (Table 2), the samples reveal petroleum potentials that are very poor $(0.13 \mathrm{~kg} / \mathrm{t}$ and less) to nil. At the same time the OC contents are so poor ( $0.12 \mathrm{wt} . \%$ and less) that the $\mathrm{H}$ and $\mathrm{O}$ indices cannot be considered. The very poor $\mathrm{OC}$ content corresponds to a considerable alteration of the OM. Thus, oxygenated environments of deposition can be deduced for all the samples from the other units of Cretaceous age, Units 5 to 7 . This is related to sedimentation of these Cretaceous units noted in the shipboard report: the sediments comprise a classic progradational submarine fan sequence where turbidite structures are present throughout.

At this point, some answers to the questions posed in the introduction can be proposed.

First, part of the organic matter present in the black beds depends on detrital organic material transported by turbidity currents. Nevertheless, the remainder of the organic matter comes from marine organic material of autochthonous origin. A second answer is related to the previous one-namely, anoxic conditions are required for preservation of this easily oxidizable marine material. A high biological oxygen demand may be one of the factors for maintaining anoxic conditions below the water/sediment interface. In addition, the main factor in establishing these anoxic conditions must be searched for in relation to the cyclic variations-in amount and composition-of the organic matter as this has been found and described previously on several scales, i.e., via an elemental sequence, then for a bundle of sequences, and lastly for a set of bundles.

\section{Climatic Factors Affecting the Sedimentation and Distribution of the Organic Matter in the Black-Shale Unit}

During the past 600,000 years, an average duration of 84,000 years has been assigned for the major climatic cycles (Ruddiman and McIntyre, 1976); 82,000 years were proposed by Mélières (1979) through three cycles of the early Albian time along DSDP Sites 400 and 402 . An order of magnitude of 100,000 years is generally considered for such climatic cycles.

An average cycle duration of the same order of magnitude (76,000 years) is obtained for each sequence along Unit 8 of Hole 530A, supposing that each numbered black bed belongs to one cycle sequence and that the cores recovered represent the whole unit. Moreover the black-shale facies (Cores 77 to 105) is supposed to cover the $20 \mathrm{~m} . \mathrm{y}$. of the early Coniacian to late Albian interval, according to on-board nannoplankton analyses.

In addition to considerations of duration, climatic variations can account for the cycles or sequences when applied to a barred depression or basin, such as the An- 

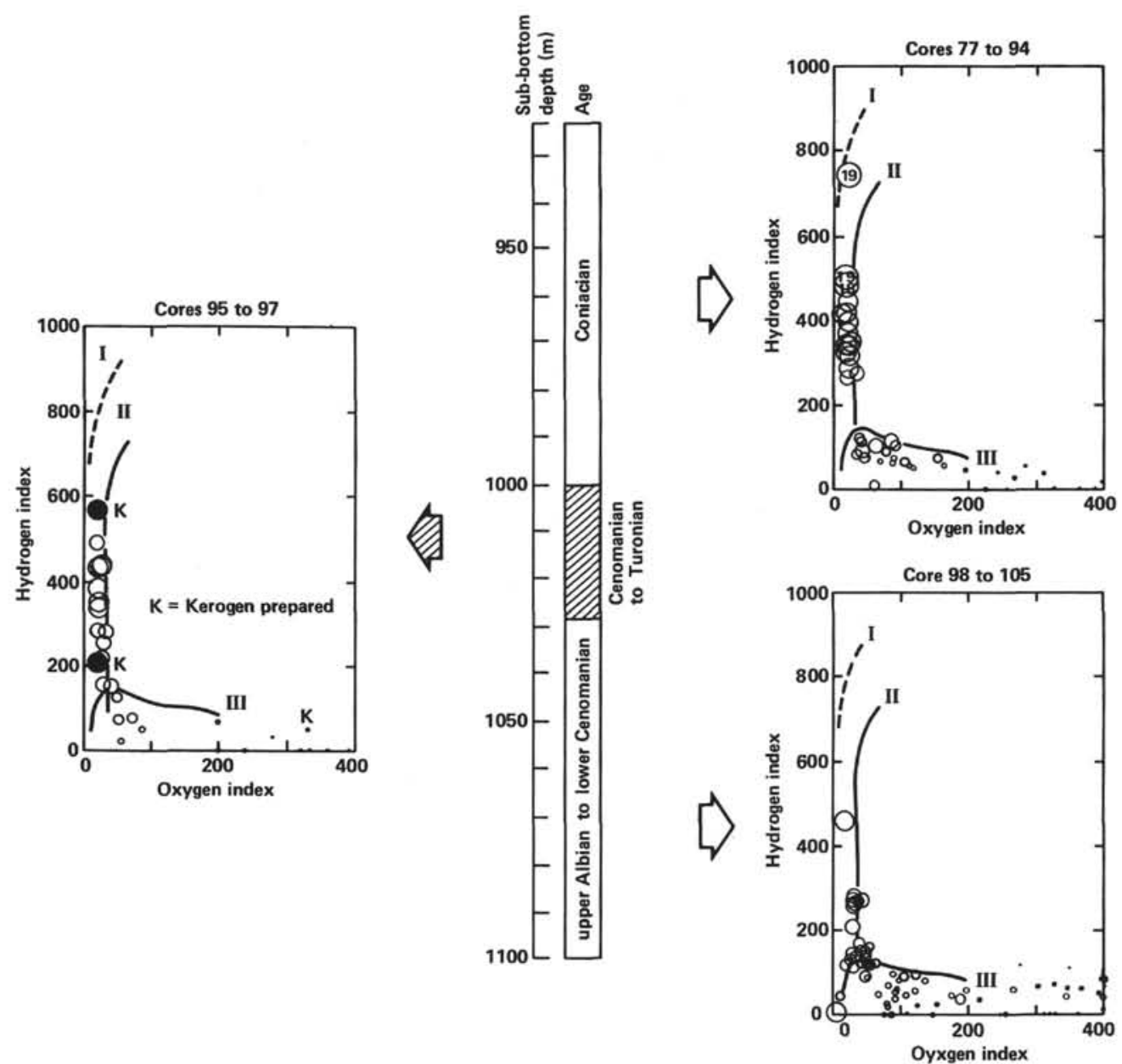

Figure 11. Diagram of hydrogen index versus oxygen index along the stratigraphic divisions of Unit 8 .

gola Basin during the Albian to Coniacian periods. Regardless of the size of the basin, deep-sea circulation must be similar to what occurred in the recent Black Sea (Redfield et al., 1965). Thus the fundamental mechanism depends on the water balance (Demaison et al., 1980), which is controlled in turn by climatic factors, i.e., whether or not arid periods predominate over wet ones, in which case a change in the water balance occurs.

The predominance of an arid period induces a negative water balance with oxygenated waters, while the wet period is too poorly developed to modify that balance. An arid phase also implies a low to nil influx of runoff and clastics. Since the basin is highly oxygenated, only impoverished deeply altered marine organic matter reaches the water/sediment interface. Calcareous tests of nannoplankton and foraminifers contribute carbonate material, and the organic matter content is low to nil. During the wet phase only some highly resistant organic matter recycled from eroded land arrives in the basin. It represents the black deposits disjointed by bioturbation and distributed as discrete streaks in the marlstones.

When wet periods predominate over arid ones until a warm but continuously wet climate develops, a positive water balance prevails throughout a barred marine ba$\mathrm{sin}$. As a result of nutrient richness, marine organisms proliferate, and anoxic environments develop on the bot- tom. In turn, marine organic matter can easily be preserved in black beds. Influxes of clastics, nutrient salts, and recycled organic matter depend on the seasonal rhythm and intensity of run-off and precipitation. This organic matter represents the detrital component observed in most black beds. When only soluble material is carried to the basin, enrichments of marine organic matter occur. The supply of nutrients and absence of detrital organic matter in runoff explain these enrichments. If such conditions continue for a long time in a quiescent environment, bacterial anaerobic activity develops on the bottom, and aliphatic enrichment of the organic matter is observed, so that organic-rich black beds occur.

Consequently, climatic change can be proposed to explain the cyclic variation of organic matter along the black-bed sequences. Two different scales have to be considered: a hundred years or less for every elemental unit of deposition including a thin (1 $\mathrm{mm}$ or less) blackstreak, and tens of thousands of years for every sequence including a black bed. The latter corresponds to the duration of a major climatic cycle, while the former may represent a seasonal fluctuations.

\section{ACKNOWLEDGMENTS}

The authors are indebted to Dr. J. Thiede, University of Oslo, for his positive criticisms and comments when reviewing this paper. 


\section{REFERENCES}

Castex, H., Rouchache, J., and Boulet, R., 1974. Le soufre thiophénique dans les pétroles et les extraits de roche. Analyse par spectrométrie de masse et chromatographie en phase gazeuse. Rev. Inst. Fr. Pétrole, 24(1):3-40.

Demaison, G. J., and Moore, G. T., 1980. Anoxic environments and oil source bed genesis. Org. Geochem., 2:9-31.

Espitalié, J., Laporte, J. L., Madec, M., Marquis, F., Leplat, P., Paulet, J., and Boutefeu, A., 1977. Méthode rapide de caractérisation des roches-mères, de leur potentiel pétrolier et de leur degré d'évolution. Rev. Inst. Fr. Pétrole, 32(1):3-40.

Espitalié, J., Madec, M., and Tissot, B., 1980. Role of mineral matrix in kerogen pyrolysis: Influence on petroleum generation and migration. Bull. Am. Assoc. Petrol. Geol., 64(1):59-66.

Huc, A. Y., Durand, B., and Monin, J. C., 1978. Humic compounds and kerogen in cores from Black Sea sediments, Leg 42B, Holes 379A,B and 380A. In Ross, D., Neprochnov, Y. P., et al., Init. Repts. DSDP, 42, Pt. 2: Washington (U.S. Govt. Printing Office), 737-748.

Melieres, F., 1979. Mineralogy and geochemistry of selected Albian sediments from the Bay of Biscay, Deep Sea Drilling Project Leg
48. In Montadert, L., Roberts, D. G., et al., Init. Repts. DSDP, 48: Washington (U.S. Govt. Printing Office), 855-875.

Redfield, A. C., Ketchum, B. H., and Richards, F. A., 1965. The influence of organisms on the composition of sea water. In Hill, M. N. (Ed.), The Sea (Vol. 2): New York (Wiley), 26-27.

Roucaché, J., Deroo, G., and Boulet, R., 1979. Caractérisation par différentes méthodes physico-chimiques de types de matière organique dans des sédiments du Crétacé d'Atlantique en mer profonde. Rev. Inst. Fr. Pétrole, 34(2):191-220.

Ruddiman, W. F., and McIntyre, A., 1976. Northeast Atlantic paleoclimatic changes over the past 600,000 years. Investigations of Late Quaternary Paleoceanography and Paleoclimatology. Geol. Soc. Am. Mem., 141:111-146.

Tissot, B. Deroo, G., and Herbin, J. P., 1979. Organic matter in Cretaceous sediments of the North Atlantic: Contribution to sedimentology and paleogeography. In Talwani, M., Hay, W., and Ryan, W. B. F. (Eds.), Deep Drilling Results in the Atlantic Ocean: Continental Margins and Paleoenvironment. Am. Geophys. Union, Maurice Ewing Series 3:362-374.

Tissot, B., Durand, B., Espitalié, J., and Combaz, A., 1974. Influence of the nature and diagenesis of organic matter in the formation of petroleum. Am. Assoc. Petrol. Geol. Bull., 58:499-506. 